\title{
Hypercoordinated Oligosilanes Based on Aminotrisphenols
}

\author{
Mohammad Aghazadeh Meshgi, ${ }^{\dagger}$ Kirill V. Zaitsev, ${ }^{*}+\odot$ Mikhail V. Vener, ${ }^{\S}$ Andrei V. Churakov, \\ Judith Baumgartner, ${ }^{\dagger}$ and Christoph Marschner*,†॰
}

\author{
${ }^{\dagger}$ Institute of Inorganic Chemistry, Graz University of Technology, Stremayrgasse 9, 8010 Graz, Austria \\ ${ }^{\ddagger}$ Department of Chemistry, Moscow State University, Leninskye Gory 1, Moscow 119991, Russia \\ ${ }^{\S}$ Department of Quantum Chemistry, Mendeleev University of Chemical Technology, Miusskaya Square 9, 125047 Moscow, Russia \\ ${ }^{\| N}$.S. Kurnakov Institute of General and Inorganic Chemistry, Russian Academy of Sciences, Leninskii pr., 31, 119991 Moscow, \\ Russia
}

\section{Supporting Information}

ABSTRACT: The hypercoordinated silicon chlorides ClSi$\left[\left(o-\mathrm{OC}_{6} \mathrm{H}_{4}\right)_{3} \mathrm{~N}\right](3)$ and $\mathrm{ClSi}\left[\left(\mathrm{OC}_{6} \mathrm{H}_{2} \mathrm{Me}_{2} \mathrm{CH}_{2}\right)_{3} \mathrm{~N}\right](5)$ were used for the synthesis of catenated derivatives $\left(\mathrm{Me}_{3} \mathrm{Si}\right)_{3} \mathrm{SiSi}$ $\left[\left(o-\mathrm{OC}_{6} \mathrm{H}_{4}\right)_{3} \mathrm{~N}\right](9),\left(\mathrm{Me}_{3} \mathrm{Si}\right)_{3} \mathrm{SiSiMe}_{2} \mathrm{SiMe}_{2} \mathrm{Si}\left(\mathrm{SiMe}_{3}\right)_{2} \mathrm{Si}[(o-$ $\left.\left.\mathrm{OC}_{6} \mathrm{H}_{4}\right)_{3} \mathrm{~N}\right](11)$, and $\left(\mathrm{Me}_{3} \mathrm{Si}\right)_{3} \mathrm{SiSi}\left[\left(\mathrm{OC}_{6} \mathrm{H}_{2} \mathrm{Me}_{2} \mathrm{CH}_{2}\right)_{3} \mathrm{~N}\right]$ (13) in reactions with $\left(\mathrm{Me}_{3} \mathrm{Si}\right)_{3} \mathrm{SiK} \cdot \mathrm{THF}(7)$ or $\left(\mathrm{Me}_{3} \mathrm{Si}\right)_{3} \mathrm{SiK}$. [18-crown-6] (8). It was found that the nature of the $\left(\mathrm{Me}_{3} \mathrm{Si}\right)_{3} \mathrm{SiK}$ solvate determines the product of interaction, resulting in the formation of $\left(\mathrm{Me}_{3} \mathrm{Si}\right)_{3} \mathrm{Si}\left(\mathrm{CH}_{2}\right)_{4} \mathrm{OSi}$ -

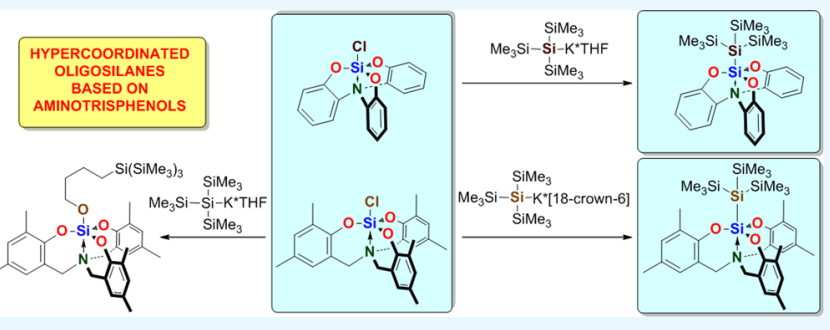
$\left[\left(\mathrm{OC}_{6} \mathrm{H}_{2} \mathrm{Me}_{2} \mathrm{CH}_{2}\right)_{3} \mathrm{~N}\right](12)$ or 13. Compounds obtained were characterized using multinuclear NMR and UV-vis spectroscopy and mass spectrometry. The molecular structures of 3, 9, and 11-13 were investigated by single-crystal X-ray analysis, featuring hypercoordinated $\mathrm{Si}$ atoms in a trigonal-bipyramidal coordination environment with $\mathrm{O}$ atoms in the equatorial plane. The structure of the side product $\left[\mathrm{N}\left(\mathrm{CH}_{2} \mathrm{C}_{6} \mathrm{H}_{2} \mathrm{Me}_{2} \mathrm{O}\right)_{3} \mathrm{Si}\right]_{2} \mathrm{O}(6)$ was also studied, indicating highly tetrahedrally distorted trigonal-bipyramidal environment at the $\mathrm{Si}$ atoms, which was confirmed by crystal density functional theory calculations indicating the very weak $\mathrm{Si} \leftarrow \mathrm{N}$ interaction. The $\mathrm{Si} \cdots \mathrm{N}$ interatomic distances span a broad range (2.23$2.78 \AA$ ). The dependence of structural and NMR parameters for hypercoordinated catenated compounds from the type of the ligand was established.

\section{INTRODUCTION}

Currently, the organometallic chemistry of group 14 elements $(\mathrm{E}=\mathrm{Si}, \mathrm{Ge}, \mathrm{Sn}, \mathrm{Pb} ; \mathrm{E}(\mathrm{IV}))$ comprises two main directions of development, including catenated (containing $\mathrm{E}-\mathrm{E}$ bonds) ${ }^{1}$ and hypercoordinated (with coordination number of $\mathrm{E}$ being higher than 4$)^{2}$ compounds. This is due to academic interest and also due to broad practical applications in chemistry. ${ }^{3}$ Work with silicon compounds serves as a model of other group 14 derivatives but is also advantageous with respect to its special features (like magnetic activity of ${ }^{29} \mathrm{Si}$ ), high abundance, and low cost for possible practical application.

In general, hypercoordination of chemical compounds is usually achieved by applying special ligands, like triethanolamine, $\mathrm{N}\left(\mathrm{CH}_{2} \mathrm{CH}_{2} \mathrm{OH}\right)_{3}$, resulting in this case in the formation of atrane molecules. ${ }^{4}$ Compounds of this type are very valuable in various fields such as organic synthesis, ${ }^{5}$ medicine, ${ }^{6}$ sol-gel techniques, ${ }^{7}$ and material chemistry. ${ }^{8}$ The increased stability of such derivatives based on tetradentate $\mathrm{O}_{3} \mathrm{~N}$-type ligands is a characteristic feature. Nevertheless, application of other ONpolydentate ligands for hypercoordinated Si compounds (like tridentate iminophenols, ${ }^{9}$ tridentate alkanoloaminophenols, ${ }^{10}$ tetradentate salens, ${ }^{11}$ and others) is also known. Furthermore, there are several cases of application of other types of $\mathrm{O}_{3} \mathrm{~N}$ ligands, like aminotrisphenols, ${ }^{12}$ homotrialkanolamines, ${ }^{13}$ and aminotris(alkylphenol)s ${ }^{14}$ or alkanolaminobis(phenol)s ${ }^{15}$ for $S i$ derivatives.

Influence of hypercoordination on the structure and UV-vis absorption properties of oligosilane properties was studied previously by El-Sayed et al. who utilized amide side chains. ${ }^{16}$ Extending the types of ligands in the synthesis of catenated derivatives increases the range of substances and their possible application, and it opens new possibilities to study structureproperty relationships. Due to $\sigma$-conjugation along the $\mathrm{E}-\mathrm{E}$ bonds, catenated compounds exhibit useful properties, such as luminescence, ${ }^{17}$ conductivity, ${ }^{18}$ and so on. Therefore, the synthesis of a wide range of catenated hypercoordinated compounds may be regarded as an actual scientific area of interest.

Although some hypercoordinated oligosilanes based on polydentate ligands are known and even have found application (e.g., in cross-coupling reactions ${ }^{19}$ ), in general their range is really very narrow ${ }^{20-22}$ (Scheme 1$)$.

The aim of the present work is the synthesis of molecular hypercoordinated oligosilanes, based on polydentate amino-

Received: June 20, 2018

Accepted: August 17, 2018

Published: August 31, 2018 
Scheme 1. Known Hypercoordinated Oligosilanes Based on Polydentate Ligands
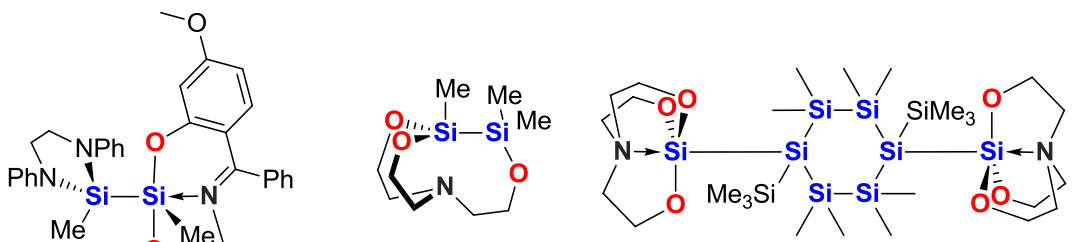

Grobe et al.

Marschner et al.

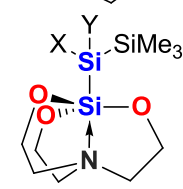

$X=\mathrm{SiMe}_{3} \mathrm{SiMe}_{2} \mathrm{Bu}-t, \mathrm{Ph}$

$\mathrm{Y}=\mathrm{H}, \mathrm{Me}, \mathrm{Et}, \mathrm{Ph}, \mathrm{SiMe}_{3}, \mathrm{~K}, \mathrm{Hf}(\mathrm{Cp})_{2} \mathrm{Cl}$

Marschner et al.

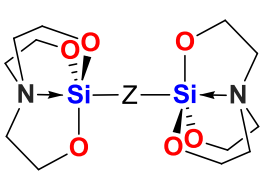

$\mathrm{Z}=\mathrm{SiMe}_{2}-\mathrm{SiMe}_{2}, \mathrm{Si}\left(\mathrm{SiMe}_{3}\right)_{2}$

Marschner et al.

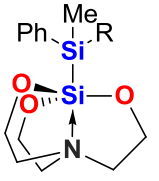

$\mathrm{R}=\mathrm{Me}, \mathrm{Ph}$ phenols, and the establishment of their structures and properties. In continuation of our works on hypercoordinated group 14 catenated derivatives, ${ }^{1 f, 23,22 a, b, 24}$ the synthesis of molecular oligosilanes $\mathbf{9 - 1 1}$ and $\mathbf{1 3}$ is reported in this work.

\section{RESULTS AND DISCUSSION}

Synthesis. In the current study, two types of ligands, aminotrisphenols $\mathbf{1}$ and 2, were used (Scheme 2). These ligands

\section{Scheme 2. Ligands 1 and 2, Used for the Synthesis of} Hypercoordinated Oligosilanes
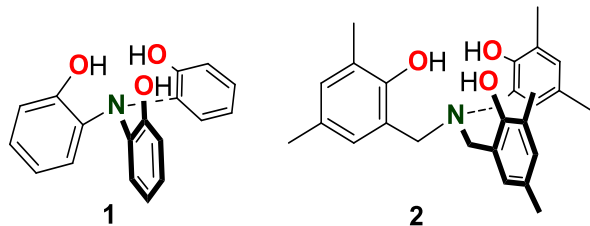

are phenols and therefore significantly different in structure from previously investigated trialkanolamine derivatives; furthermore, they are also different with respect to the nature of the donating nitrogen atom, which is either bound directly to the aromatic ring (as in $\mathbf{1}$ ) or not (in 2). Ligand $\mathbf{1}$ forms rigid fivemembered chelates with a $\mathrm{Si}$ atom, while ligand $\mathbf{2}$ forms more flexible six-membered chelates. This structural difference may result in divergent properties in silatranes based on $\mathbf{1}$ and 2 .

Both compounds are known, but for 1 , $^{12 a}$ an improved synthetic protocol and analytical data are provided (for details, see the Experimental Section).

According to previous experiments, the best way for the attachment of the silatrane unit to a polysilane chain is to react a silatranyl electrophile containing a suitable leaving group with a silanide. ${ }^{19 a, 22 a}$ Therefore, silatranyl-like chlorides 3 and $\mathbf{5}$ were obtained at the first stage. Chloride 3 was prepared following the procedure reported by Frye et al. (Scheme 3 ). ${ }^{12 a}$ Removal of the formed $\mathrm{HCl}$ in this case is possible due to low basicity of the anilinic $\mathrm{N}$ of $\mathbf{1}$. Compound 3 was isolated as a beige powder, stable in dry atmosphere and sparingly soluble in polar common organic solvents (chloroform, dichloromethane).

Despite the successful synthesis of $\mathbf{3}$, similar synthetic ways to 5 did not work out. Neither reaction of silyl ether $\mathrm{N}\left(\mathrm{CH}_{2} \mathrm{C}_{6} \mathrm{H}_{2} \mathrm{Me}_{2} \mathrm{OSiMe}_{3}\right)_{3}$ with $\mathrm{SiCl}_{4}$ under prolonged heating in toluene, as was used for the synthesis of ClSi-
Scheme 3. Synthesis of Hypercoordinated Chlorosilanes 3 and 5

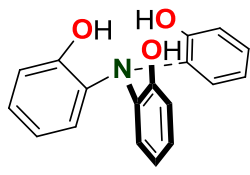

1

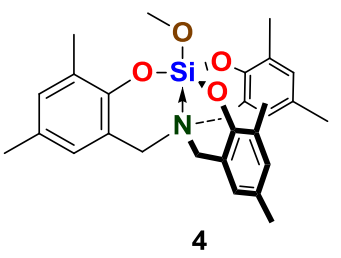

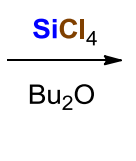

$\mathrm{SOCl}_{2}$

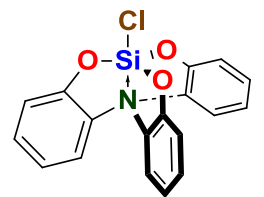

$3(71 \%)$

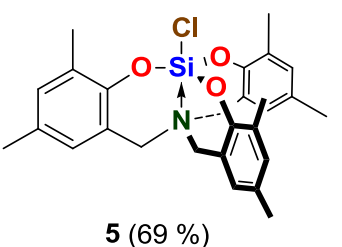

$\left(\mathrm{OCH}_{2} \mathrm{CH}_{2}\right)_{3} \mathrm{~N},{ }^{22 \mathrm{a}}$ nor reaction of free $\mathrm{N}\left(\mathrm{CH}_{2} \mathrm{C}_{6} \mathrm{H}_{2} \mathrm{Me}_{2} \mathrm{OH}\right)_{3}$ with $\mathrm{SiCl}_{4}$ in the presence of $\mathrm{Et}_{3} \mathrm{~N}$ did result in formation of the target compound. The synthesis of each hypercoordinated derivative critically depends on the type of the ligand used. An alternative procedure was devised, involving synthesis of alkoxy derivative $\mathbf{4}$ according to the literature procedure reported by Holmes et al., ${ }^{14 a}$ followed by chlorination as known for related compounds. ${ }^{25}$ Thus, $\operatorname{MeOSi}\left[\left(\mathrm{OC}_{6} \mathrm{H}_{2} \mathrm{Me}_{2} \mathrm{CH}_{2}\right)_{3} \mathrm{~N}\right]$ (4) was reacted with excess thionyl chloride for $18 \mathrm{~h}$ to obtain $\left[\mathrm{N}\left(\mathrm{CH}_{2} \mathrm{C}_{6} \mathrm{H}_{2} \mathrm{Me}_{2} \mathrm{O}\right)_{3}\right] \mathrm{SiCl}$ (5) (Scheme 3).

Compound $\mathbf{5}$ was isolated as a white powder, soluble in common organic solvents, which much to our surprise is highly moisture sensitive. During the crystallization of $\mathbf{5}$ from chloroform at ambient conditions, crystals of hydrolyzed product, $\mathrm{HCl} \cdot \mathrm{N}\left(\mathrm{CH}_{2} \mathrm{C}_{6} \mathrm{H}_{2} \mathrm{Me}_{2} \mathrm{OH}\right)_{3}(\mathbf{2} \cdot \mathrm{HCl}$ ) (Figure $\mathrm{S} 1$, Supporting Information (SI)), were obtained. Furthermore, during recrystallization of the reaction mixture after synthesis of 13 (Scheme 6; see below), crystals of [N$\left.\left(\mathrm{CH}_{2} \mathrm{C}_{6} \mathrm{H}_{2} \mathrm{Me}_{2} \mathrm{O}\right)_{3} \mathrm{Si}\right]_{2} \mathrm{O}$ (6) (Figure 2), suitable for singlecrystal X-ray analysis, were obtained (Scheme 4 ); in this case, 6 was formed from unreacted $\mathbf{5}$. The formation of different products under random hydrolysis of hypercoordinated $\mathbf{5}$ is explained by the appearance or presence of trace amounts of acidic or basic catalysts ${ }^{4 a, 26,56}$ under reaction conditions. ${ }^{14 \mathrm{c}}$ It should be noted that related $\mathrm{O}\left[\mathrm{Si}\left(o-\mathrm{OC}_{6} \mathrm{H}_{4}\right)_{3} \mathrm{~N}\right]_{2}$ may be obtained by hydrolysis of $\operatorname{AcOSi}\left(o-\mathrm{OC}_{6} \mathrm{H}_{4}\right)_{3} \mathrm{~N}$. 
Scheme 4. Schematic Representation of Random Hydrolysis of 5

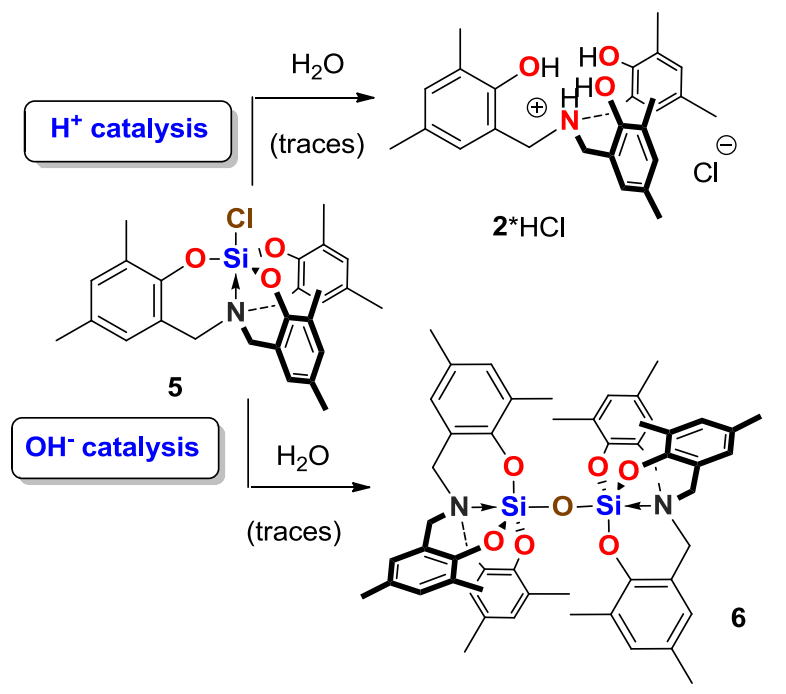

For the synthesis of the targeted hypercoordinated oligosilanes, in a second step chlorides $\mathbf{3}$ and $\mathbf{5}$ were reacted with potassium silanide reagents. Thus, oligosilanylsilatrane 9 was prepared by reaction of oligosilanylpotassium 7 with $\mathrm{ClSi}(o-$ $\left.\mathrm{OC}_{6} \mathrm{H}_{4}\right)_{3} \mathrm{~N}$ (3) (Scheme 5). NMR spectroscopy of the reaction mixture showed exclusive formation of 9 without any observable side products, like hydrosilane $\left(\mathrm{Me}_{3} \mathrm{Si}\right)_{3} \mathrm{SiH}$. In contrast, the reaction of oligosilanylpotassium 7 with 1-chlorosilatrane

Scheme 5. Synthesis of Compounds 9-11 Using Silyl Potassium Reagents
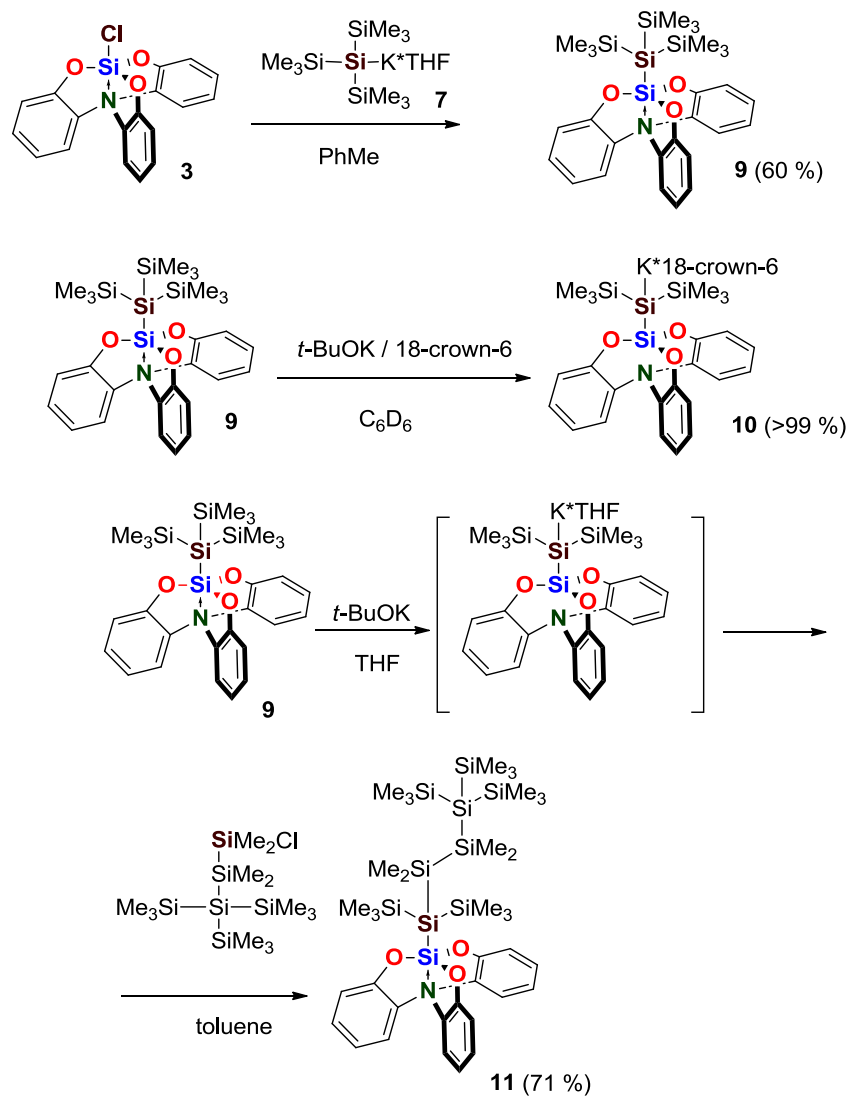

$\mathrm{ClSi}\left(\mathrm{OCH}_{2} \mathrm{CH}_{2}\right)_{3} \mathrm{~N}$ did not proceed cleanly ${ }^{22 \mathrm{a}}$ due to its lower reactivity, explained by the unusual geometry. ${ }^{27}$

Compound 9 was successfully metallated by $t$-BuOK/18crown-6 giving 10, which is sufficiently stable and was characterized by multinuclear NMR spectroscopy (for details, see the Experimental Section); compounds related to $\mathbf{1 0}$ may be used for the synthesis of other derivatives. Thus, metallation of 9 with in situ formation of the related potassium reagent followed by reaction with $\left(\mathrm{Me}_{3} \mathrm{Si}\right)_{3} \mathrm{SiSiMe}_{2} \mathrm{SiMe}_{2} \mathrm{Cl}$ gave compound $\mathbf{1 1}$ (Scheme 5).

In contrast to the synthesis of 9 , reaction of oligosilanylpotassium reagent 7 with $\left[\mathrm{N}\left(\mathrm{CH}_{2} \mathrm{C}_{6} \mathrm{H}_{2} \mathrm{Me}_{2} \mathrm{O}\right)_{3}\right] \mathrm{SiCl}$ (5) unexpectedly gave oligosilanylsilatrane $\mathbf{1 2}$ (Scheme 6). According

Scheme 6. Synthesis of 12 and 13 by Reaction of Chloride 5 with Oligosilanylpotassium Reagents 7 and 8

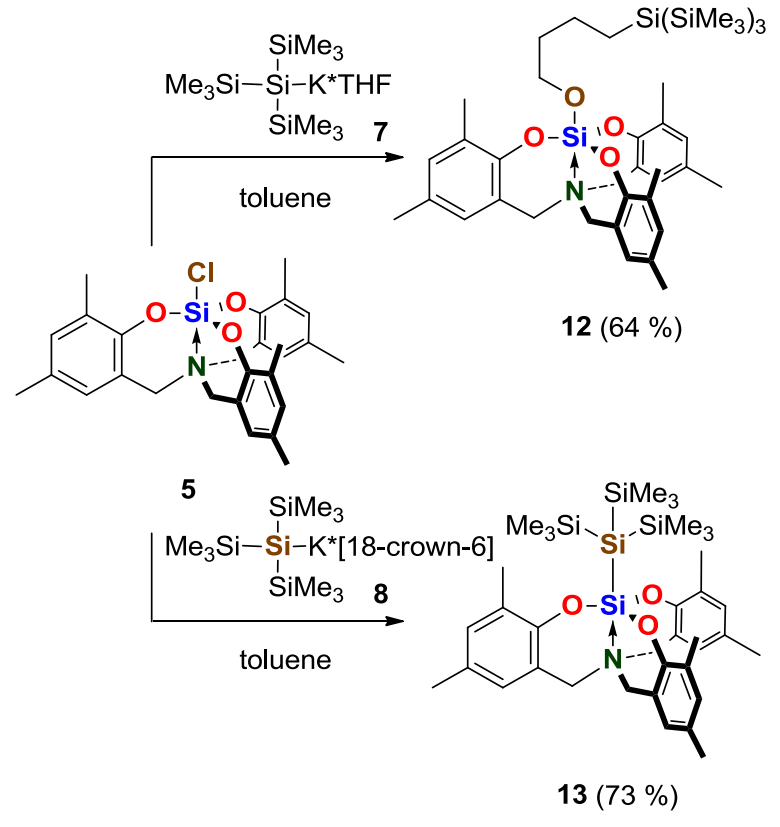

to crystal structure analysis of $\mathbf{1 2}$ (Figure 4), tetrahydrofuran (THF) ring opening occurred, with the oxygen atom of the THF attached to the hypercoordinated silicon atom and the $\alpha$-carbon atom of THF bound to the oligosilanyl unit.

The formation of oligosilanylsilatrane $\mathbf{1 2}$ is a typical case of THF opening in the presence of strong Lewis acids. We have observed related chemistry previously for instance in the reaction of silanide 7 and related substances with $\mathrm{HfCl}_{4}^{28}$ and $\mathrm{YbI}_{2}{ }^{24}$ In this occasion, compound 5 may be regarded as Lewis acid also (compare with the results of Holmes and co-workers, who have reported a new class of silatrane-like molecules $\left[\mathrm{N}\left(\mathrm{CH}_{2} \mathrm{C}_{6} \mathrm{H}_{2} \mathrm{Me}_{2} \mathrm{O}\right)_{3}\right] \mathrm{SiX}\left(\mathrm{X}=\mathrm{Me}, \mathrm{OMe}, \mathrm{Ph}, \mathrm{CCl}_{3}\right)^{14 \mathrm{a}}$ with acidic $\mathrm{Si}$ atoms). Coordination of THF to 5 activates the $\alpha$ position of THF toward the nucleophilic attack of silanide 7 , which then is the actual ring-opening event.

Oligosilanylsilatrane 13 was eventually prepared by reaction of tris(trimethylsilyl)silyl potassium $\cdot 18$-crown-6 (8) with [N$\left.\left(\mathrm{CH}_{2} \mathrm{C}_{6} \mathrm{H}_{2} \mathrm{Me}_{2} \mathrm{O}\right)_{3}\right] \mathrm{SiCl}$ (5) (Scheme 6). To avoid THF ring opening such as in the previous reaction, oligosilylanylpotassium 8 was prepared in toluene in the presence of 18 -crown- 6 . Therefore, the course of the reaction with silyl potassium reagents strongly depends on the nature of this reagent.

The difference in reactivities of $\mathbf{3}$ and $\mathbf{5}$ toward oligosilanides deserves additional explanation. Explanation including "spillover 
effect" ${ }^{29}$ (increase of acidity of hypercoordinated group 14 center) may be regarded as implausible. Apparently, the increase of this bond length of $\mathbf{5}$ is explained by the more flexible ligand framework and also is based on the dissociation of $\mathrm{N} \rightarrow \mathrm{Si}$ interaction (compare with dynamic NMR behavior and in related derivatives based on X-ray diffraction (XRD); see below) with significant geometry distortion at $\mathrm{Si}$ (from five- to fourcoordinated) and thereby increase of acidity ("strain release Lewis acidity"). ${ }^{30}$

Compounds 9, 11, 12, and 13 were isolated as colorless crystalline materials, stable under ambient conditions and soluble in common organic solvents. The identities of compounds were established by elemental analysis and mass spectrometry (MS), and structures were studied by multinuclear NMR spectroscopy $\left({ }^{1} \mathrm{H},{ }^{13} \mathrm{C},{ }^{29} \mathrm{Si}\right)$ in solution; X-ray singlecrystal diffraction analysis (XRD) was used for investigation of structures $2 \cdot \mathrm{HCl}$ (Figure S1, Supporting Information), 3, 6, 9, and 11-13 in solid state. The degree of conjugation along the $\mathrm{Si}-\mathrm{Si}$ bond was studied by UV-vis spectroscopy.

Crystal Structures. The molecular structures of compounds 3, 6, 9, and 11-13 (Figures 1-6) in the solid state were

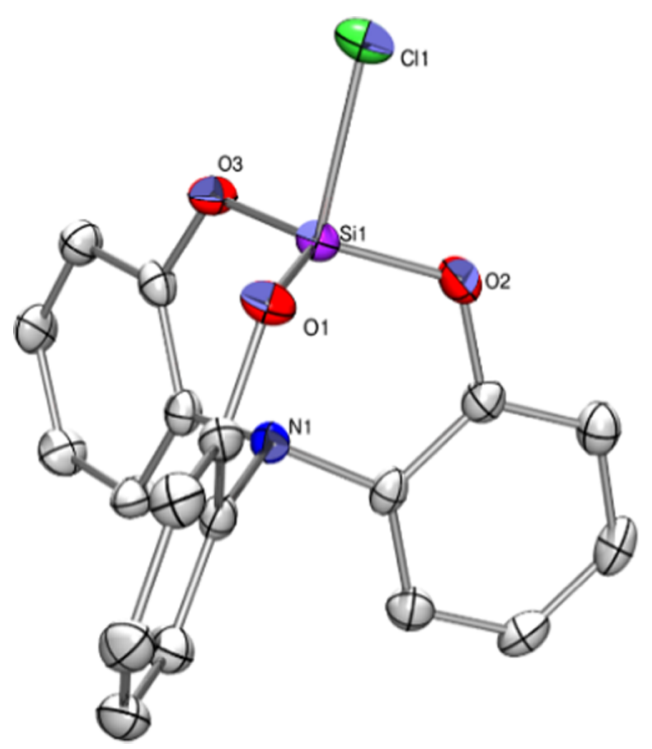

Figure 1. Molecular structure of $\mathrm{ClSi}\left[\left(o-\mathrm{OC}_{6} \mathrm{H}_{4}\right)_{3} \mathrm{~N}\right](3)$ in the crystal. Hydrogen atoms are omitted for clarity. Selected bond lengths $(\AA)$ and angles (deg): $\mathrm{Si}(1)-\mathrm{N}(1)$ 2.2125(17), $\mathrm{Si}(1)-\mathrm{O}(1)$ 1.6526(17), $\mathrm{Si}(1)-\mathrm{O}(2) \quad 1.6544(17), \mathrm{Si}(1)-\mathrm{O}(3) 1.6514(16), \mathrm{Si}(1)-\mathrm{Cl}(1)$ 2.0707(8), $\mathrm{Cl}(1)-\mathrm{Si}(1)-\mathrm{N}(1)$ 179.23(5), O(3)-Si(1)-O(1) 119.18(9), O(3)-Si(1)-O(2) 117.74(9), O(1)-Si(1)-O(2) 119.23(9), $\mathrm{O}(3)-\mathrm{Si}(1)-\mathrm{Cl}(1)$ 95.92(6), $\mathrm{O}(1)-\mathrm{Si}(1)-\mathrm{Cl}(1)$ 97.13(6), $\mathrm{O}(3)-\mathrm{Si}(1)-\mathrm{N}(1)$ 83.44(7), $\mathrm{C}(12)-\mathrm{N}(1)-\mathrm{C}(22)$ $114.49(17)$, and $\mathrm{C}(12)-\mathrm{N}(1)-\mathrm{Si}(1)$ 103.46(13).

investigated by single-crystal XRD analysis. A main question in the investigation of these structures is the study of the level of $\mathrm{N}$ $\rightarrow \mathrm{SiO}_{3}-\mathrm{X}$ interaction, its influence on the trans-Si-X bond, and the establishment of coordination geometry around the central Si atom (tetrahedral vs trigonal bipyramidal (TBP)). It should be noted that for the case of catenated compounds, the rules, found earlier for silatranes (more electron-withdrawing groups $\mathrm{X}$ in $\mathrm{N} \rightarrow \mathrm{Si}-\mathrm{X}$ fragment result in shortening of the $\mathrm{Si}-\mathrm{N}$ bond), are not so evident due to the equal nature of silicon atoms $\left(\mathrm{X}=\mathrm{SiR}_{3}\right)$. According to the Cambridge Structural Database (CSD, February 2018), ${ }^{31}$ the $\mathrm{Si}-\mathrm{N}$ bond varies within $1.965^{32}-$ $2.333^{22 \mathrm{~b}} \AA$ in silatranes, within $2.025^{14 \mathrm{a}}-2.839^{14 \mathrm{~b}}$ in benzyl silatrane-like molecules based on 2 and related ligands, and within $2.256-2.344^{12 \mathrm{~b}} \AA$ A for phenylene silatrane-like molecules based on 1 and related ligands, wherein for the last case the variation range is the smallest one due to the rigid structure of the ligand. XRD investigations indicate that substitution of the ethylene bridge in silatranes by phenylene and benzylene groups results in increased $\mathrm{Si}-\mathrm{N}$ distances. ${ }^{2 \mathrm{a}}$

Chlorosilatrane-like molecule 3 (Figure 2) was found to crystallize in the monoclinic space group $P 2_{1} / n$. The geometry

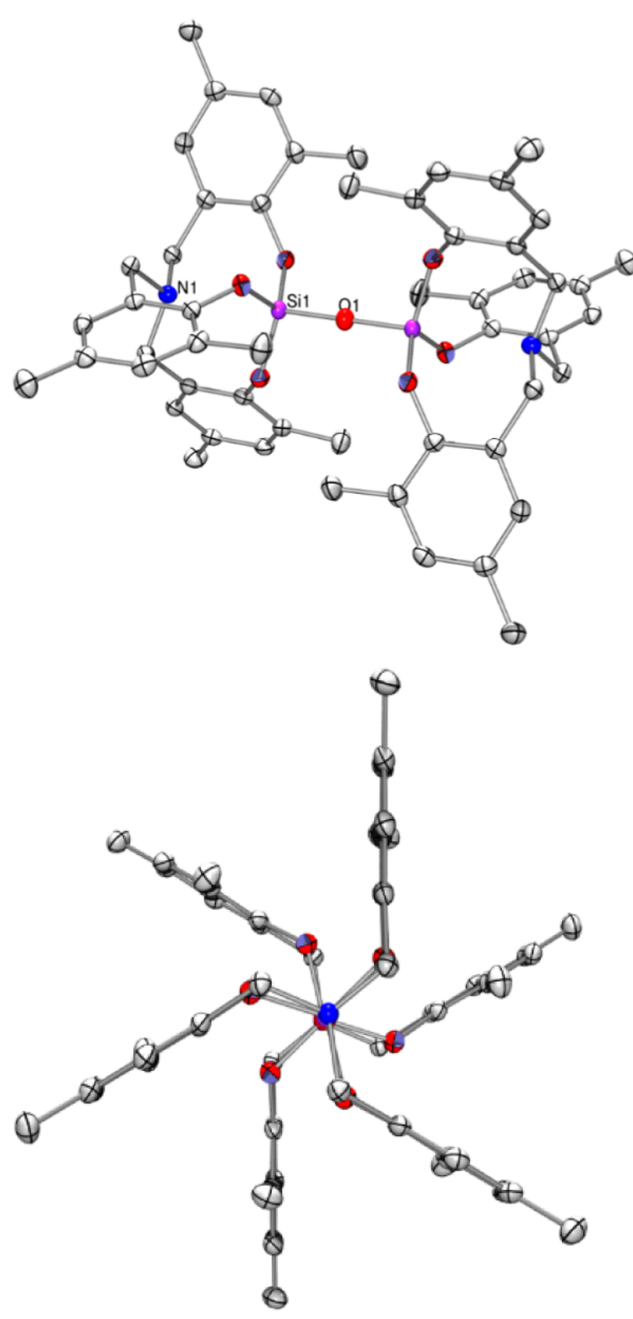

Figure 2. Molecular structure of $\left[\mathrm{N}\left(\mathrm{CH}_{2} \mathrm{C}_{6} \mathrm{H}_{2} \mathrm{Me}_{2} \mathrm{O}\right)_{3} \mathrm{Si}\right]_{2} \mathrm{O}(6)$ in the crystal (top: view perpendicular to the $\mathrm{Si}-\mathrm{O}-\mathrm{Si}$ axis; bottom: view along the $\mathrm{Si}-\mathrm{O}-\mathrm{Si}$ axis). There are two molecules in the asymmetric unit. Hydrogen atoms are omitted for clarity. Selected interatomic distances $(\AA)$ and angles (deg): $\mathrm{Si}(1)-\mathrm{O}(1)$ 1.6094(6), $\mathrm{Si}(1)-\mathrm{O}(2)$ 1.6274(9), $\mathrm{Si}(1) \cdots \mathrm{N}(1) \quad 2.7730(9) ; \mathrm{O}(1)-\mathrm{Si}(1)-\mathrm{O}(2)$ 104.11(4), $\mathrm{O}(2)-\mathrm{Si}(1)-\mathrm{O}(2 \mathrm{~A})$ 114.26(3), $\mathrm{Si}(1)-\mathrm{O}(1)-\mathrm{Si}(1)$ 180.00(4), $\mathrm{N}(1)-\mathrm{Si}(1)-\mathrm{O}(1)$ 179.97(3), and $\mathrm{N}(1)-\mathrm{Si}(1)-\mathrm{O}(2) 75.90(4)$.

around the $\mathrm{Si}$ atom may be described as slightly (angle $\mathrm{Cl}(1)-$ $\mathrm{Si}(1)-\mathrm{N}(1)$ is $179.23(5)^{\circ}$, the sum of angles at $\mathrm{Si}$ atom is $356.15^{\circ}$ ) distorted trigonal bipyramid (TBP-5) with $\mathrm{Cl}$ and $\mathrm{N}$ atoms in apical positions; in general, the molecule possesses approximate $C_{3}$ symmetry. The $\mathrm{N}$ atom of 3 adopts a tetrahedral geometry (angle's sum is $344.38^{\circ}$ ). Although the structure of chlorosilatrane-like molecule 3 , due to the presence of phenyl groups, is not as flexible (the plane of each $\mathrm{C}_{6} \mathrm{H}_{4}$ cycle is coplanar with condensed five-membered chelate ring) as the structure of silatranes with alkylamine groups, XSi- 
$\left(\mathrm{OCH}_{2} \mathrm{CH}_{2}\right)_{3} \mathrm{~N}$, the $\mathrm{Si}-\mathrm{N}$ bond length in $3(2.2125 \AA)$ is significantly longer than the $\mathrm{Si}-\mathrm{N}$ bond in $\mathrm{ClSi}\left(\mathrm{OCH}_{2} \mathrm{CH}_{2}\right)_{3} \mathrm{~N}$ $(2.023 \AA)^{27}$ or in $\mathrm{ClSi}\left(\mathrm{OC}_{6} \mathrm{H}_{2} \mathrm{Me}(t-\mathrm{Bu}) \mathrm{CH}_{2}\right)_{3} \mathrm{~N}(2.045 \AA) .{ }^{14 \mathrm{c}}$ This in fact shows to some extent the mobility of the $\mathrm{Si}-\mathrm{N}$ bond even in the presence of three phenyl groups in the structure of 3 . Another difference among the structures of $\mathrm{ClSi}\left(o-\mathrm{OC}_{6} \mathrm{H}_{4}\right)_{3} \mathrm{~N}$ (3), $\mathrm{ClSi}\left(\mathrm{OCH}_{2} \mathrm{CH}_{2}\right)_{3} \mathrm{~N}$, and $\mathrm{ClSi}\left(\mathrm{OC}_{6} \mathrm{H}_{2} \mathrm{Me}(t-\mathrm{Bu}) \mathrm{CH}_{2}\right)_{3} \mathrm{~N}$ is the difference of $\mathrm{Si}-\mathrm{Cl}$ bond lengths $(2.0707,2.153$, and 2.180 $\AA$, respectively), whereas $\mathrm{Si}-\mathrm{O}$ bonds (alkoxide and phenoxide) are almost identical $(1.6528,1.649$, and $1.629 \AA)$. Comparison of these three related structures indicates the dependence of the structural parameters from the ligand used, where the flexibility of the chelate rings is the most important.

Compound 6 (Figure 2) crystallizes in the trigonal space group $R \overline{3}$; the molecule occupies a threefold axis. According to the Cambridge Crystallographic Database (CSD), structures with $\mathrm{Si}^{\mathrm{V}}-\mathrm{O}-\mathrm{Si}^{\mathrm{V}}$ coordination motif are very rare, ${ }^{26 c, 33}$ and there are no structures with $\mathrm{SiNO}_{4}$ coordination of such type. The main features of 6 consist of an almost linear $\mathrm{N}-\mathrm{Si}-\mathrm{O}-\mathrm{Si}-\mathrm{N}$ fragment and a staggered conformation of two $\mathrm{NSiO}_{3}$ frameworks along the $\mathrm{Si}-\mathrm{O}-\mathrm{Si}$ bond, which may be explained by steric reasons. The introduction of two voluminous $\mathrm{Si}\left(\mathrm{OC}_{6} \mathrm{H}_{2} \mathrm{Me}_{2} \mathrm{CH}_{2}\right)_{3} \mathrm{~N}$ units to $\mathrm{O}$ not only contributes to its linearity, but also led to sufficient increase of the $\mathrm{Si}-\mathrm{N}$ distance $(2.7730$ in 6 vs $2.633 \AA$ in related $\mathrm{MeOSi}$ $\left.\left(\mathrm{OC}_{6} \mathrm{H}_{2} \mathrm{Me}_{2} \mathrm{CH}_{2}\right)_{3} \mathrm{~N}\right)^{14 \mathrm{a}}$ and $\mathrm{Si}-\mathrm{O}_{\mathrm{eq}}$ bonds (1.6274 vs 1.616 $\AA$ ), whereas the $\mathrm{Si}-\mathrm{O}_{\mathrm{ax}}$ distances are almost identical (1.6094 vs $1.609 \AA$ A). At the same time, $\mathrm{C}-\mathrm{N}-\mathrm{Si}-\mathrm{O}$ are almost in eclipsed conformation in deference of other cases. Apparently, there is very weak $\mathrm{N} \rightarrow \mathrm{Si}$ interaction in 6 (2.7730 vs $1.965-2.838 \AA$, typical for silatranes and related compounds; see above), ${ }^{2 a}$ and the $\mathrm{Si}$ atom has a highly tetrahedrally distorted trigonalbipyramidal geometry, which was additionally confirmed by crystal density functional theory (DFT) calculations (see below). Six-membered chelate $\mathrm{OSiNC}_{3}$ cycles are in almost ideal boat conformations, where the $\mathrm{O}$ and $\mathrm{CH}_{2}$ units are the ones that moved out of the plane formed by the other atoms.

According to the crystallographic data of oligosilanylsilatrane 9 (Figure 3), two molecules of 9 with noticeably different structural parameters are in the asymmetric unit in the monoclinic space group $\mathrm{C} 2 / \mathrm{c}$. The $\mathrm{Si}-\mathrm{N}$ bond length increases from $2.2125 \AA$ in $\mathrm{ClSi}\left(o-\mathrm{OC}_{6} \mathrm{H}_{4}\right)_{3} \mathrm{~N}$ (3) or $2.292 \AA$ in $\left(\mathrm{Me}_{3} \mathrm{Si}\right)_{3} \mathrm{SiSi}\left(\mathrm{OCH}_{2} \mathrm{CH}_{2}\right)_{3} \mathrm{~N}^{22 \mathrm{a}}$ to 2.455 and $2.509 \AA$ in oligosilanylsilatrane 9 , which shows the flexibility of the silatrane cage and the mobility of nitrogen atom even in the presence of three rigid phenylene groups. In reverse $\mathrm{Si}-\mathrm{SiO}_{3}$ bond lengths decrease from $2.3509 \AA$ in $\left(\mathrm{Me}_{3} \mathrm{Si}\right)_{3} \mathrm{SiSi}\left(\mathrm{OCH}_{2} \mathrm{CH}_{2}\right)_{3} \mathrm{~N}$ to 2.3096 and $2.3245 \AA$ in oligosilanylsilatrane 9. This fact can be explained by the electron-withdrawing character of the phenylene groups in the ligand framework. Unequal values of three $\mathrm{O}(x)-\mathrm{Si}(1)-\mathrm{O}\left(x^{\prime}\right)$ angles (for details, see the Supporting Information) in spite of approximate $C_{3}$ symmetry in the structure along the $\mathrm{Si}-\mathrm{SiO}_{3}$ bond is due to torsion in the silatranyl group, which is created by three rigid phenylene groups. In 9 , the hypercoordinated silicon atoms $\mathrm{Si}(1) / \mathrm{Si}(6)$ have a distorted TBP-5 geometry with $\mathrm{N}$ and $\mathrm{Si}(2)$ atoms in apical positions.

For 9, the whole molecule has a staggered conformation along $\mathrm{Si}(1)-\mathrm{Si}(2)$ bond (torsion $\mathrm{Si}-\mathrm{Si}(2)-\mathrm{Si}(1)-\mathrm{O}$ is $65.21(8) /$ $\left.54.78(8)^{\circ}\right)$. The nitrogen atom is highly flattened (sum of the angles is $351.22 / 353.70^{\circ}$ ). The five-membered chelate cycles are in distorted envelope conformation with $\mathrm{Si}$ atom as a flap.

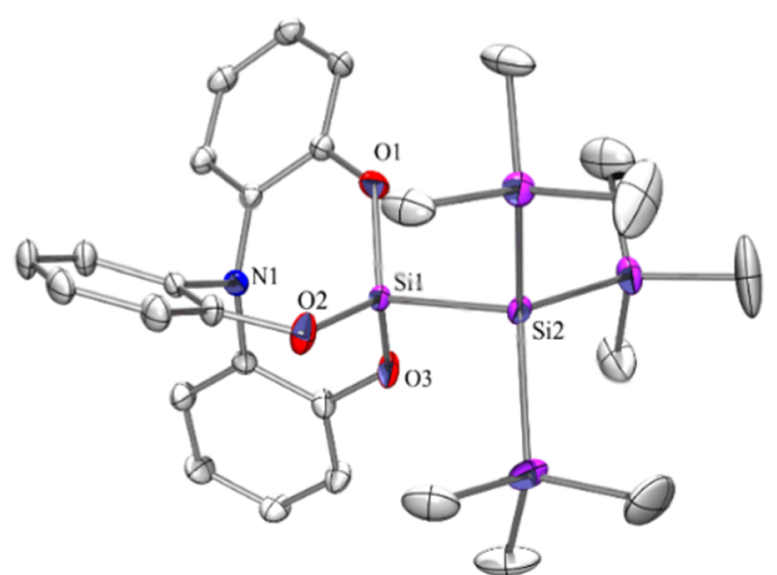

Figure 3. Molecular structure of 1,1,1-aminotris(phenyl-2'-oxy)-2,2bis(trimethylsilyl)trimethyltrisilane (9) in the crystal. There are two molecules in the asymmetric unit; only one molecule is shown. Hydrogen atoms are omitted for clarity. Selected bond lengths $(\AA)$ and angles (deg): molecule 1: $\mathrm{Si}(1)-\mathrm{N}(1)$ 2.5090(17), $\mathrm{Si}(1)-\mathrm{O}(1)$ 1.6500(17), $\mathrm{Si}(1)-\mathrm{O}(2)$ 1.6583(17), $\mathrm{Si}(1)-\mathrm{O}(3)$ 1.6487(16), $\mathrm{Si}(1)-\mathrm{Si}(2)$ 2.3096(9), $\mathrm{Si}(2)-\mathrm{Si}(5) 2.3380(10), \mathrm{Si}(2)-\mathrm{Si}(1)-\mathrm{N}(1)$ 178.31(10), $\mathrm{Si}(2)-\mathrm{Si}(1)-\mathrm{O}(1)$ 103.30(6), $\mathrm{O}(1)-\mathrm{Si}(1)-\mathrm{O}(2)$ 114.48(10), $\mathrm{N}(1)-\mathrm{Si}(1)-\mathrm{O}(1)$ 76.05(10), $\mathrm{C}(6)-\mathrm{N}(1)-\mathrm{C}(14)$ 118.21(17), $\mathrm{C}(8)-\mathrm{N}(1)-\mathrm{Si}(1)$ 98.05(17); molecule 2 : $\mathrm{Si}(6)-\mathrm{N}(2)$ 2.4550(16), $\mathrm{Si}(6)-\mathrm{O}(4)$ 1.6564(15), $\mathrm{Si}(6)-\mathrm{O}(5)$ 1.6555(16), Si(6)$\mathrm{O}(6) 1.6575(16), \mathrm{Si}(6)-\mathrm{Si}(7) 2.3245(9), \mathrm{Si}(7)-\mathrm{Si}(9) 2.3426(9)$, $\mathrm{Si}(7)-\mathrm{Si}(6)-\mathrm{N}(2)$ 178.40(9), $\mathrm{Si}(7)-\mathrm{Si}(6)-\mathrm{O}(4)$ 102.96(6), O(5)$\mathrm{Si}(6)-\mathrm{O}(6) 115.61(9), \mathrm{N}(2)-\mathrm{Si}(6)-\mathrm{O}(5) 77.68(9), \mathrm{C}(26)-\mathrm{N}(2)-$ $\mathrm{C}(24) 117.95(16)$, and $\mathrm{C}(24)-\mathrm{N}(2)-\mathrm{Si}(6)$ 99.78(16).

For 11 (monoclinic space group $P 2_{1} / c$; Figure 4 ), the $\mathrm{Si}-$ $\mathrm{SiO}_{3}$ bond is shortened $(2.319$ vs $2.347-2.377 \AA)$ in comparison with the other ones. The nitrogen atom is again highly flattened (sum of the angles is $350.31^{\circ}$ ). The geometry of hypercoordinated $\mathrm{Si}(2)$ may be described as distorted TBP-5

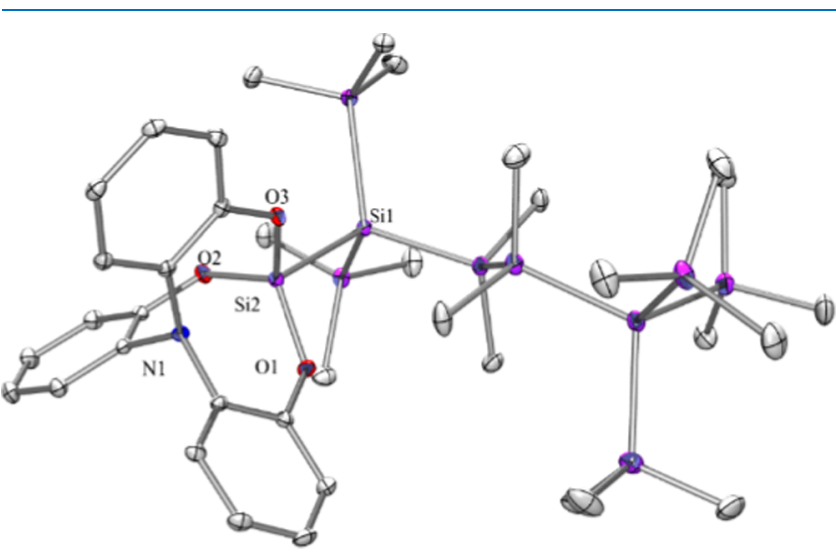

Figure 4. Molecular structure of $\mathbf{1 1}$ in the crystal. Hydrogen atoms are omitted for clarity. Selected bond lengths $(\AA)$ and angles (deg): $\mathrm{Si}(2)-$ $\mathrm{O}$ (1) 1.6702(15), $\mathrm{Si}(2)-\mathrm{O}(2)$ 1.6723(15), $\mathrm{Si}(2)-\mathrm{O}(3)$ 1.6804(15), $\mathrm{Si}(2)-\mathrm{N}$ 2.4170(15), Si(1)-Si(2) 2.3191(8), Si(1)-Si(4) 2.3478(8), $\mathrm{Si}(1)-\mathrm{Si}(3)$ 2.3508(8), $\mathrm{Si}(1)-\mathrm{Si}(5)$ 2.3575(8), $\mathrm{Si}(5)-\mathrm{Si}(6)$ 2.3682(9), $\mathrm{Si}(6)-\mathrm{Si}(7)$ 2.3766(9), $\mathrm{Si}(7)-\mathrm{Si}(9)$ 2.3533(9), Si(7)$\mathrm{Si}(8)$ 2.3588(9), $\mathrm{Si}(7)-\mathrm{Si}(10) 2.3600(9), \mathrm{N}(1)-\mathrm{Si}(2)-\mathrm{Si}(1)$ 177.63(19), N(1)-Si(2)-O(1) 78.01(19), O(2)-Si(2)-O(3) 115.26(8), $\mathrm{O}(1)-\mathrm{Si}(2)-\mathrm{Si}(1) \quad 102.27(6), \mathrm{C}(6)-\mathrm{N}(1)-\mathrm{C}(12)$ 116.88(15), $\quad \mathrm{C}(6)-\mathrm{N}(1)-\mathrm{Si}(2) \quad 100.47(19), \quad \mathrm{Si}(2)-\mathrm{Si}(1)-\mathrm{Si}(5)$ $111.20(3), \quad \mathrm{Si}(1)-\mathrm{Si}(5)-\mathrm{Si}(6) \quad 117.59(3), \mathrm{Si}(5)-\mathrm{Si}(6)-\mathrm{Si}(7)$ 114.46(3), and $\mathrm{Si}(9)-\mathrm{Si}(7)-\mathrm{Si}(6) 114.12(3)$. 
with the oxygen atoms in the equatorial plane; five-membered chelate rings are in envelope conformations with $\mathrm{Si}$ as a valve. Conformation along $\mathrm{Si}-\mathrm{Si}-\mathrm{Si}-\mathrm{O}$ is staggered (torsions are $42.53 / 77.47^{\circ}$ ); $\sigma$-conjugation along the $\mathrm{Si}-\mathrm{Si}$ bonds is possible (angle $\mathrm{Si}-\mathrm{Si}-\mathrm{Si}$ varies in the $111-118^{\circ}$ range; $120^{\circ}$ for the ideal conjugation), but the terminal silicon atoms deviate from the planarity with the central ones. Comparison of the structural parameters of $\mathbf{9}$ and $\mathbf{1 1}$ indicates that the elongation of the silicon chain as substituent at hypercoordinated $\mathrm{Si}$ atom resulted in significant changes in the $\mathrm{Si}-\mathrm{N}$ bond, which may be explained by steric and packing reasons.

According to the crystallographic data, there are two molecules of oligosilanylsilatrane $\mathbf{1 2}$ in the asymmetric unit; the structural parameters are significantly different possibly due to packing effects (Figure 5). Compound $\mathbf{1 2}$ crystallizes in the

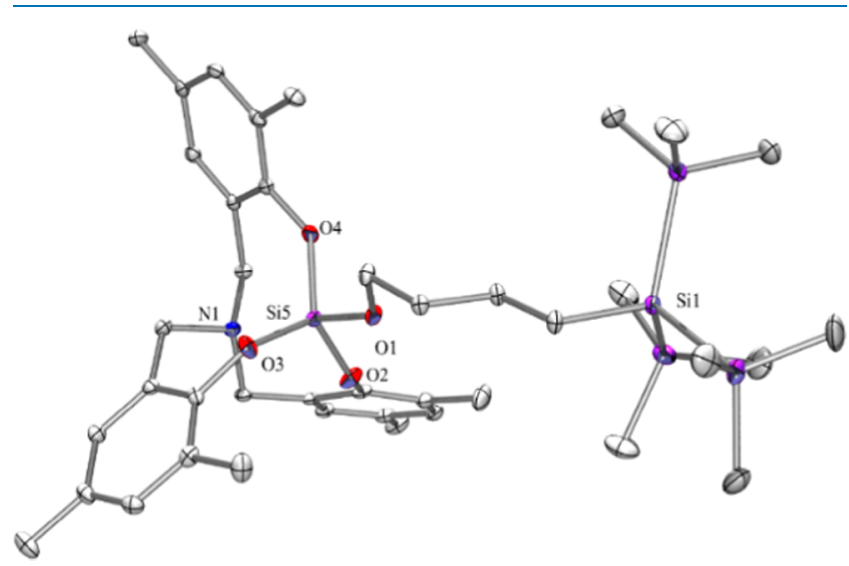

Figure 5. Molecular structure of $\mathrm{N}\left[\mathrm{CH}_{2}\left(\mathrm{Me}_{2} \mathrm{C}_{6} \mathrm{H}_{2}\right) \mathrm{O}\right]_{3} \mathrm{SiO}\left(\mathrm{CH}_{2}\right)_{4} \mathrm{Si}-$ $\left(\mathrm{SiMe}_{3}\right)_{3}(12)$ in the crystal. There are two molecules in the asymmetric unit, and one of them has a disorder in the $\left(\mathrm{CH}_{2}\right)_{4}$ bridge; only one molecule is shown. Hydrogen atoms are omitted for clarity. Selected bond lengths $(\AA)$ and angles (deg): molecule 1 : $\mathrm{Si}(5)-\mathrm{N}(1) 2.527(3)$, $\mathrm{Si}(5)-\mathrm{O}(1)$ 1.644(2), $\mathrm{Si}(5)-\mathrm{O}(2)$ 1.624(3), $\mathrm{Si}(5)-\mathrm{O}(3)$ 1.632(3), $\mathrm{Si}(5)-\mathrm{O}(4) 1.635(3), \mathrm{N}(1)-\mathrm{Si}(5)-\mathrm{O}(1)$ 176.04(14), O(1) $-\mathrm{Si}(5)-$ $\mathrm{O}(2)$ 95.83(13), O(1)-Si(5)-O(3) 101.29(13), O(3)-Si(5)-O(4) 113.69(14), O(2)-Si(5)-O(4) 122.81(14), N(1)-Si(5)-O(3) 80.81(13), $\mathrm{C}(20)-\mathrm{N}(1)-\mathrm{C}(39)$ 110.1(3); molecule 2: $\mathrm{Si}(10)-$ $\mathrm{N}(2) \quad 2.717(3), \quad \mathrm{Si}(10)-\mathrm{O}(5) \quad 1.619(3), \mathrm{Si}(10)-\mathrm{O}(6) 1.629(2)$, $\mathrm{Si}(10)-\mathrm{O}(7)$ 1.631(3), $\mathrm{Si}(10)-\mathrm{O}(8)$ 1.624(3), $\mathrm{N}(2)-\mathrm{Si}(10)-\mathrm{O}(5)$ 177.18(16), O(5)-Si(10)-O(7) 103.05(16), O(7)-Si(10)-O(6) 111.86(13), $\mathrm{O}(7)-\mathrm{Si}(10)-\mathrm{O}(8)$ 117.31(13), N(2)-Si(10)-O(7) 77.01(16), and $\mathrm{C}(69)-\mathrm{N}(2)-\mathrm{C}(81) 110.7(3)$.

triclinic space group $P \overline{1}$, where the coordination geometry of $\mathrm{Si}(5)$ may be described as TBP-5 with $\mathrm{N}$ and $\mathrm{O}(1)$ in apical positions. $\mathrm{Si}-\mathrm{N}$ bonds of 2.527 and $2.717 \AA$ and $\mathrm{O}-\mathrm{SiO}_{3}$ bonds of 1.644 and $1.619 \AA$, respectively, were observed, which means that the structure with a shorter $\mathrm{Si}-\mathrm{N}$ bond has a longer $\mathrm{O}-$ $\mathrm{SiO}_{3}$ bond, and in contrast, the structure with a longer $\mathrm{Si}-\mathrm{N}$ bond has a shorter $\mathrm{O}-\mathrm{SiO}_{3}$ bond. This in fact is in accordance with Gordon's rule. ${ }^{34}$ Unequal values of three $\mathrm{O}(x)-\mathrm{Si}(5)-$ $\mathrm{O}\left(x^{\prime}\right)$ angles (for details, see the Supporting Information) with close to $10^{\circ}$ difference are mainly caused by the alkylene chain of THF, which is located between the silatranyl and $\left(\mathrm{Me}_{3} \mathrm{Si}\right)_{3} \mathrm{Si}$ groups. In contrast to three unequal $\mathrm{O}(x)-\mathrm{Si}(5)-\mathrm{O}\left(x^{\prime}\right)$, three $\mathrm{C}(x)-\mathrm{N}(1)-\mathrm{C}\left(x^{\prime}\right)$ angles are very close to each other. Although the $\mathrm{O}(x)-\mathrm{Si}(5)-\mathrm{O}\left(x^{\prime}\right)$ units are under steric tension, the torsion does not transfer to the three $\mathrm{C}(x)-\mathrm{N}(1)-\mathrm{C}\left(x^{\prime}\right)$ angles due to the flexibility of the silatranyl ligand. The sixmembered chelate rings are in boat conformation with $\mathrm{O}$ and
$\mathrm{CH}_{2}$ as valves. Comparing the structural parameters of $\mathbf{1 2}$ (both molecules) to those of $\mathbf{6}$ indicates significant changes in $\mathrm{Si}-\mathrm{N}$ bond length $(2.527,2.717$ vs $2.773 \AA$ ) but only insignificantly influences the equatorial $\mathrm{Si}-\mathrm{O}$ bonds (1.630, 1.628 vs 1.6274 $\AA$ ), whereas the changes in axial $\mathrm{Si}-\mathrm{O}$ bonds are more significant (1.644, 1.619 vs $1.6094 \AA$, respectively), indicating the strong effect of hypercoordination in the $\mathrm{X}-\mathrm{Si} \leftarrow \mathrm{N}$ fragment.

The molecule of oligosilanylsilatrane 13 (Figure 6) crystallizes in the trigonal space group $P \overline{3} c 1$. Due to the

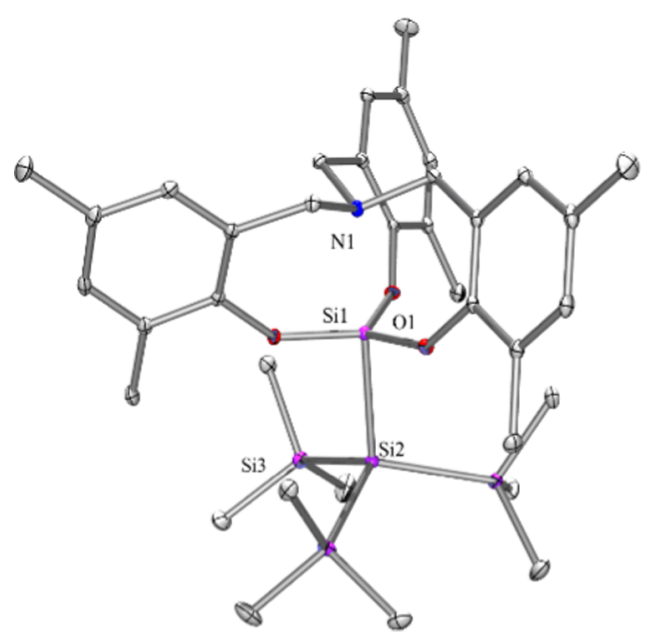

Figure 6. Molecular structure of 1,1,1-aminotris $\left(-3^{\prime}, 5^{\prime}\right.$-dimethylbenzyl$2^{\prime}$-oxy)-2,2-bis(trimethylsilyl)trimethyltrisilane (13) in the crystal. Hydrogen atoms are omitted for clarity. Selected bond lengths $(\AA)$ and angles (deg): $\mathrm{Si}(1)-\mathrm{N}(1)$ 2.237(4), $\mathrm{Si}(1)-\mathrm{O}(3)$ 1.6669(18), $\mathrm{Si}(1)-\mathrm{Si}(2)$ 2.3770(17), $\mathrm{Si}(2)-\mathrm{Si}(3) 2.3818(9), \mathrm{N}(1)-\mathrm{Si}(1)-\mathrm{Si}(2)$ $180.000(1), \quad \mathrm{O}(1)-\mathrm{Si}(1)-\mathrm{N}(1)$ 84.83(7), O (1)-Si(1)-Si(2) 95.17(7), $\mathrm{O}(1)-\mathrm{Si}(1)-\mathrm{O}(1) \quad 119.20(2)$, and $\mathrm{C}(9)-\mathrm{N}(1)-\mathrm{C}(9)$ 109.11(17).

presence of a symmetry axis along the $\mathrm{N}-\mathrm{Si}-\mathrm{Si}$ bond, three $\mathrm{O}(x)-\mathrm{Si}(1)-\mathrm{O}\left(x^{\prime}\right)$ angles as well as three $\mathrm{C}(x)-\mathrm{N}(1)-\mathrm{C}\left(x^{\prime}\right)$ angles are equal to each other (for details, see the Supporting Information). However, the related oligosilanylsilatrane $\left(\mathrm{Me}_{3} \mathrm{Si}\right)_{3} \mathrm{SiSi}\left(\mathrm{OCH}_{2} \mathrm{CH}_{2}\right)_{3} \mathrm{~N}^{22 \mathrm{a}}$ with the trialkylamine ligand or oligosilanylsilatrane 9 with the triphenylenamine ligand are symmetric molecules, but a symmetric crystal structure was not observed in their case.

The hypercoordinated atom $\mathrm{Si}(1)$ in $\mathbf{1 3}$ features trigonal bipyramidal (TBP-5) geometry with oxygen atoms in equatorial positions. The torsional angles along $\mathrm{Si}-\mathrm{Si}-\mathrm{Si}-\mathrm{O}$ (torsions are $\left.56.71 / 63.36^{\circ}\right)$ indicate a staggered conformation; six-membered chelate cycles are in half-chair conformation with $\mathrm{N}$ and $\mathrm{CH}_{2}$ in vertices.

It is interesting to compare structural data for the related catenated derivatives $13,\left(\mathrm{Me}_{3} \mathrm{Si}\right)_{3} \mathrm{SiSi}\left(\mathrm{OCH}_{2} \mathrm{CH}_{2}\right)_{3} \mathrm{~N},{ }^{22 \mathrm{a}}$ and 9 with the hypercoordinated $\mathrm{Si}$ atom in a similar $\mathrm{SiSiO}_{3} \mathrm{~N}$ coordination environment. Elongation of $\mathrm{Si} \leftarrow \mathrm{N}$ bonds apparently is caused by the rigid ligand structure (geometric reason) $\left(2.237\right.$ in $13,2.292$ in $\left(\mathrm{Me}_{3} \mathrm{Si}\right)_{3} \mathrm{SiSi}\left(\mathrm{OCH}_{2} \mathrm{CH}_{2}\right)_{3} \mathrm{~N}$, and $2.455 / 2.509 \AA \AA$ in 9) and accompanied by shortening of the $\mathrm{Si}-$ Si $(2.3770$ vs 2.3509 vs $2.3245 / 2.3096 \AA)$ bond. At the same time, $\mathrm{Si}-\mathrm{O}$ bonds ( 1.6669 vs 1.650 vs $1.6565 / 1.6523 \AA$ ) are changed not so evidently, possibly due to packing effects, although the same tendency is visible. Anyway, the similarity of 
Table 1. Comparison of the Main Structural Parameters for Several Hypercoordinated Oligosilanes

\begin{tabular}{|c|c|c|c|c|}
\hline compound & $\mathrm{Si}-\mathrm{N}, \AA$ & $\Delta, \AA$ & average $\mathrm{O}-\mathrm{Si}-\mathrm{N}-\mathrm{C}$ torsion, deg & reference \\
\hline$\left[\mathrm{Me}_{2} \mathrm{OSi}\left(\mathrm{OCH}_{2} \mathrm{CH}_{2}\right)_{3} \mathrm{~N}\right]\left[\mathrm{BF}_{4}\right]$ & 1.965 & -0.017 & 16.44 & 32 \\
\hline $\mathrm{ClSi}\left(\mathrm{OCH}_{2} \mathrm{CH}_{2}\right)_{3} \mathrm{~N}$ & 2.023 & -0.095 & 9.16 & 27 \\
\hline$\left(\mathrm{Me}_{3} \mathrm{Si}\right)_{3} \mathrm{SiSi}\left(\mathrm{OCH}_{2} \mathrm{CH}_{2}\right)_{3} \mathrm{~N}$ & 2.292 & -0.267 & 9.70 & $22 \mathrm{a}$ \\
\hline cyclo- $\left(\mathrm{Si}_{6}\left(\mathrm{SiMe}_{3}\right)_{2} \mathrm{Me}_{8}\right)\left(\mathrm{Si}\left(\mathrm{OCH}_{2} \mathrm{CH}_{2}\right)_{3} \mathrm{~N}\right)$ & 2.333 & -0.291 & 8.34 & $22 b$ \\
\hline $\mathrm{Cl}_{3} \mathrm{CSi}\left[\left(\mathrm{OC}_{6} \mathrm{H}_{2} \mathrm{Me}_{2} \mathrm{CH}_{2}\right)_{3} \mathrm{~N}\right]$ & 2.025 & 0.033 & 39.0 & $14 \mathrm{a}$ \\
\hline $\mathrm{ClSi}\left[\left(\mathrm{OC}_{6} \mathrm{H}_{2} \mathrm{Me}_{2} \mathrm{CH}_{2}\right)_{3} \mathrm{~N}\right]$ & 2.045 & 0.013 & 38.07 & $14 \mathrm{c}$ \\
\hline$\left(\mathrm{Me}_{3} \mathrm{Si}\right)_{2} \mathrm{Si}(\mathrm{H}) \mathrm{Si}\left(\mathrm{OCH}_{2} \mathrm{CH}_{2}\right)_{3} \mathrm{~N}$ & 2.153 & -0.202 & 3.75 & $22 c$ \\
\hline $\operatorname{MeOSi}\left[\left(\mathrm{OC}_{6} \mathrm{H}_{2} \mathrm{Me}_{2} \mathrm{CH}_{2}\right)_{3} \mathrm{~N}\right]$ & 2.633 & -0.315 & 17.2 & $14 \mathrm{a}$ \\
\hline$(2-\mathrm{Py}) \mathrm{CH}_{2} \mathrm{CH}_{2} \mathrm{Si}\left[\left(\mathrm{OC}_{6} \mathrm{H}_{2} \mathrm{Me}_{2} \mathrm{CH}_{2}\right)_{3} \mathrm{~N}\right]$ & 2.838 & -0.439 & 6.92 & $14 \mathrm{~b}$ \\
\hline $\operatorname{PhSi}\left(o-\mathrm{OC}_{6} \mathrm{H}_{4}\right)_{3} \mathrm{~N}$ & 2.344 & -0.287 & 0 & $12 \mathrm{~b}$ \\
\hline $\mathrm{ClSi}\left(o-\mathrm{OC}_{6} \mathrm{H}_{4}\right)_{3} \mathrm{~N}(3)$ & 2.2125 & -0.189 & 2.63 & this work \\
\hline $\mathrm{O}\left(\mathrm{Si}\left[\left(\mathrm{OC}_{6} \mathrm{H}_{2} \mathrm{Me}_{2} \mathrm{CH}_{2}\right)_{3} \mathrm{~N}\right]\right)_{2}(6)$ & 2.773 & -0.397 & 5.47 & this work \\
\hline \multirow[t]{2}{*}{$\left(\mathrm{Me}_{3} \mathrm{Si}\right)_{3} \mathrm{SiSi}\left(o-\mathrm{OC}_{6} \mathrm{H}_{4}\right)_{3} \mathrm{~N}(9)$} & 2.455 & -0.352 & 9.56 & this work \\
\hline & 2.509 & -0.391 & 15.59 & \\
\hline$\left(\mathrm{Me}_{3} \mathrm{Si}\right)_{3} \mathrm{SiSiMe}_{2} \mathrm{SiMe}_{2} \mathrm{Si}\left(\mathrm{SiMe}_{3}\right)_{2} \mathrm{Si}\left(o-\mathrm{OC}_{6} \mathrm{H}_{4}\right)_{3} \mathrm{~N}(\mathbf{1 1})$ & 2.417 & -0.349 & 15.18 & this work \\
\hline \multirow[t]{2}{*}{$\left(\mathrm{Me}_{3} \mathrm{Si}\right)_{3} \mathrm{Si}\left(\mathrm{CH}_{2}\right)_{4} \mathrm{OSi}\left[\left(\mathrm{OC}_{6} \mathrm{H}_{2} \mathrm{Me}_{2} \mathrm{CH}_{2}\right)_{3} \mathrm{~N}\right]$} & 2.527 & -0.258 & 21.87 & this work \\
\hline & 2.717 & -0.361 & 11.50 & \\
\hline$\left(\mathrm{Me}_{3} \mathrm{Si}\right)_{3} \mathrm{SiSi}\left[\left(\mathrm{OC}_{6} \mathrm{H}_{2} \mathrm{Me}_{2} \mathrm{CH}_{2}\right)_{3} \mathrm{~N}\right](13)$ & 2.236 & -0.150 & 46.29 & this work \\
\hline
\end{tabular}

Table 2. ${ }^{29} \mathrm{Si}$ NMR Data of $\mathrm{SiO}_{3}$ Group for 3-5, 9-13, and Related Compounds

\begin{tabular}{|c|c|c|c|}
\hline compound & chemical shift of $\mathrm{SiO}_{3}, \delta$, ppm & solvent & reference \\
\hline$(\mathrm{MeO})_{4} \mathrm{Si}$ & -79.91 & $\mathrm{CDCl}_{3}$ & 38 \\
\hline$(\mathrm{EtO})_{4} \mathrm{Si}$ & -82.24 & $\mathrm{CDCl}_{3}$ & 38 \\
\hline$(\mathrm{PhO})_{4} \mathrm{Si}$ & -101.89 & $\mathrm{CDCl}_{3}$ & 38 \\
\hline $\mathrm{ClSi}(\mathrm{OMe})_{3}$ & -66.6 & $\mathrm{CDCl}_{3}$ & \\
\hline $\mathrm{ClSi}\left(o-\mathrm{OC}_{6} \mathrm{H}_{4} \mathrm{Ph}\right)_{3}$ & -84.79 & $\mathrm{CDCl}_{3}$ & 39 \\
\hline $\mathrm{MeOSi}\left(\mathrm{OCH}_{2} \mathrm{CH}_{2}\right)_{3} \mathrm{~N}$ & -95.4 & & 32 \\
\hline \multirow[t]{4}{*}{$\mathrm{ClSi}\left(\mathrm{OCH}_{2} \mathrm{CH}_{2}\right)_{3} \mathrm{~N}$} & -85.2 & $\mathrm{CP} / \mathrm{MAS}$ & 40 \\
\hline & -85.8 & $\mathrm{CDCl}_{3}$ & 41 \\
\hline & -86.1 & $\mathrm{CDCl}_{3}$ & 42 \\
\hline & -86.4 & $\mathrm{CP} / \mathrm{MAS}$ & 43 \\
\hline $\mathrm{ClSi}\left(o-\mathrm{OC}_{6} \mathrm{H}_{4}\right)_{3} \mathrm{~N}(3)$ & -97.8 & DMSO- $d_{6}$ & this work \\
\hline $\operatorname{MeOSi}\left[\left(\mathrm{OC}_{6} \mathrm{H}_{2} \mathrm{Me}_{2} \mathrm{CH}_{2}\right)_{3} \mathrm{~N}\right]$ & -119.0 & $\mathrm{CDCl}_{3}$ & $14 \mathrm{a}$ \\
\hline $\mathrm{ClSi}\left[\left(\mathrm{OC}_{6} \mathrm{H}_{2} \mathrm{Me}_{2} \mathrm{CH}_{2}\right)_{3} \mathrm{~N}\right](5)$ & -124.5 & $\mathrm{CDCl}_{3}$ & this work \\
\hline$\left(\mathrm{Me}_{3} \mathrm{Si}\right)_{2} \mathrm{Si}(\mathrm{K}) \mathrm{Si}\left(\mathrm{OCH}_{2} \mathrm{CH}_{2}\right)_{3} \mathrm{~N} \cdot 18$-crown-6 & -11.8 & $\mathrm{C}_{6} \mathrm{D}_{6}$ & $22 \mathrm{a}$ \\
\hline$\left(\mathrm{Me}_{3} \mathrm{Si}\right)_{2} \mathrm{Si}(\mathrm{K}) \mathrm{Si}\left(o-\mathrm{OC}_{6} \mathrm{H}_{4}\right)_{3} \mathrm{~N} \cdot 18$-crown-6 (10) & -9.5 & $\mathrm{C}_{6} \mathrm{D}_{6}$ & this work \\
\hline$\left(\mathrm{Me}_{3} \mathrm{Si}\right)_{3} \mathrm{SiSi}(\mathrm{OEt})_{3}$ & -32.2 & & $22 c$ \\
\hline$\left(\mathrm{Me}_{3} \mathrm{Si}\right)_{3} \mathrm{SiSi}\left(\mathrm{OCH}_{2} \mathrm{CH}_{2}\right)_{3} \mathrm{~N}$ & -52.6 & & $22 \mathrm{a}$ \\
\hline$\left(\mathrm{Me}_{3} \mathrm{Si}\right)_{3} \mathrm{SiSi}\left(o-\mathrm{OC}_{6} \mathrm{H}_{4}\right)_{3} \mathrm{~N}(9)$ & -45.9 & $\mathrm{CDCl}_{3}$ & this work \\
\hline$\left(\mathrm{Me}_{3} \mathrm{Si}\right)_{3} \mathrm{SiSiMe}_{2} \mathrm{SiMe}_{2} \mathrm{Si}\left(\mathrm{SiMe}_{3}\right)_{2} \mathrm{Si}\left(o-\mathrm{OC}_{6} \mathrm{H}_{4}\right)_{3} \mathrm{~N}(\mathbf{1 1})$ & -46.3 & $\mathrm{CDCl}_{3}$ & this work \\
\hline$\left(\mathrm{Me}_{3} \mathrm{Si}\right)_{3} \mathrm{SiSiMe}_{2} \mathrm{SiMe}_{2} \mathrm{Si}\left(\mathrm{SiMe}_{3}\right)_{2} \mathrm{Si}\left(\mathrm{OCH}_{2} \mathrm{CH}_{2}\right)_{3} \mathrm{~N}$ & -53.8 & $\mathrm{CDCl}_{3}$ & $22 \mathrm{a}$ \\
\hline$\left(\mathrm{Me}_{3} \mathrm{Si}\right)_{3} \mathrm{Si}\left(\mathrm{CH}_{2}\right)_{4} \mathrm{OSi}\left[\left(\mathrm{OC}_{6} \mathrm{H}_{2} \mathrm{Me}_{2} \mathrm{CH}_{2}\right)_{3} \mathrm{~N}\right]$ & -117.1 & $\mathrm{CDCl}_{3}$ & this work \\
\hline$\left(\mathrm{Me}_{3} \mathrm{Si}\right)_{3} \mathrm{SiSi}\left[\left(\mathrm{OC}_{6} \mathrm{H}_{2} \mathrm{Me}_{2} \mathrm{CH}_{2}\right)_{3} \mathrm{~N}\right]$ & -107.7 & $\mathrm{CDCl}_{3}$ & this work \\
\hline
\end{tabular}

$\mathrm{Si}-\mathrm{O}$ bond for alkoxides and phenoxides of such types should be mentioned.

Using data for 3 and 6 , it is evident that the XSi $\leftarrow \mathrm{N}$ bond length depends on the electron properties of $\mathrm{X}$ (electronwithdrawing groups result in shortening $)^{34,35}$ but also on the steric size of $\mathrm{X}$ (increasing size of $\mathrm{X}$ results in elongation of $\mathrm{X}-\mathrm{Si}$ and $\mathrm{Si} \leftarrow \mathrm{N})$. The Bader analysis of the theoretical electron density showed the presence of the bond critical point between the $\mathrm{Si}$ and $\mathrm{N}$ atoms. The electron density equals to 0.056 au for 3 and 0.021 au for 6 . The energies of the $\mathrm{Si} \leftarrow \mathrm{N}$ interaction are 43.5 and $14.2 \mathrm{~kJ} / \mathrm{mol}$ for 3 and 6 , respectively. It should be noted that in related atranes, $\mathrm{N}\left(\mathrm{CH}_{2} \mathrm{CH}_{2} \mathrm{O}\right)_{3} \mathrm{SiSi}\left(\mathrm{SiMe}_{3}\right)_{2} \mathrm{R}(\mathrm{R}=\mathrm{H}$, $\left.\mathrm{Me}, \mathrm{Et}, \mathrm{Ph}, \mathrm{SiMe}_{3}, \mathrm{SiMe}_{2} \mathrm{SiMe}_{3}, \mathrm{Si}\left(\mathrm{OCH}_{2} \mathrm{CH}_{2}\right)_{3} \mathrm{~N}\right)$, the $\mathrm{Si}-\mathrm{N}$ bond distances are in the 2.15-2.42 $\AA$ range. ${ }^{22}$ For oligosilanylsilatrane-like molecules 9 and 11 based on ligand 1, this bond is significantly elongated (up to $2.41-2.51 \AA$ ), whereas for 13 , based on ligand 2 , the $\mathrm{Si}-\mathrm{N}$ distance is in accord with typical hypercoordinated interaction. Anyway, in all compounds, the interaction is present, even in 6, despite a long $\mathrm{Si}-\mathrm{N}$ distance. These data clearly indicate the dependence of structural parameters on the ligand electronic and geometric properties. The insertion of $\mathrm{N}$ atom into the conjugation with $\mathrm{O}$ by phenylene as in $\mathbf{1}$ results in decreased electron-withdrawing properties of alkoxides at the $\mathrm{Si}$ atom. The $\mathrm{Si}-\mathrm{Si}(\mathrm{O})_{3}$ bonds in 9, 11, and 13 vary between 2.30 and $2.39 \AA$, which correlates with data for single $\mathrm{Si}-\mathrm{Si}$ bond length. The $\mathrm{Si}-\mathrm{O}$ bonds in 9,11 , and 13 based on aminotrisphenols are in the range of 1.65-1.68 $\AA$, typical for oligosilanylsiltranes, ${ }^{2 a}$ indicating a weak effect of conjugation of $\mathrm{O}$ with aryl group in phenols on Si geometry. The similarity in the $\mathrm{Si}-\mathrm{N}$ bond length for $\mathbf{1 3}$ and classical silatrane $\mathrm{N}\left(\mathrm{CH}_{2} \mathrm{CH}_{2} \mathrm{O}\right)_{3} \mathrm{SiSi}\left(\mathrm{SiMe}_{3}\right)_{3}$ reflects the role of fluxional 
Table 3. UV-Vis Absorption Data for Several Si Compounds

\begin{tabular}{|c|c|c|c|c|}
\hline compound & $\lambda, \mathrm{nm}$ & absorptivity, $\times 10^{4} \mathrm{M}^{-1} \mathrm{~cm}^{-1}$ & solvent & reference \\
\hline $\mathrm{Me}_{3} \mathrm{SiSiMe}_{2} \mathrm{SiMe}_{3}$ & 215 & 0.90 & cyclohexane & 47 \\
\hline$\left(\mathrm{Me}_{3} \mathrm{Si}\right)_{3} \mathrm{SiSiMe}_{2} \mathrm{SiMe}_{2} \mathrm{Si}\left(\mathrm{SiMe}_{3}\right)_{3}$ & 258 & 2.4 & hexane & 46 \\
\hline $\mathrm{Me}_{3} \mathrm{SiSiMe}{ }_{2} \mathrm{Si}\left(\mathrm{SiMe}_{3}\right)_{2} \mathrm{Si}\left(\mathrm{OCH}_{2} \mathrm{CH}_{2}\right)_{3} \mathrm{~N}$ & 223 & 1.85 & $n$-pentane & $22 \mathrm{a}$ \\
\hline$\left(\mathrm{Me}_{3} \mathrm{Si}\right)_{3} \mathrm{SiSiMe}_{2} \mathrm{SiMe}_{2} \mathrm{Si}\left(\mathrm{SiMe}_{3}\right)_{2} \mathrm{Si}\left(\mathrm{OCH}_{2} \mathrm{CH}_{2}\right)_{3} \mathrm{~N}$ & 254 & 5.45 & $n$-pentane & $22 \mathrm{a}$ \\
\hline$\left[\mathrm{N}\left(\mathrm{CH}_{2} \mathrm{CH}_{2} \mathrm{O}\right)_{3} \mathrm{SiSi}\left(\mathrm{SiMe}_{3}\right)_{2} \mathrm{SiMe}_{2}\right]_{2}$ & 252 & 7.48 & $\mathrm{Et}_{2} \mathrm{O}$ & $22 \mathrm{a}$ \\
\hline \multirow[t]{2}{*}{$\left(\mathrm{Me}_{3} \mathrm{Si}\right)_{3} \mathrm{SiSi}\left(o-\mathrm{OC}_{6} \mathrm{H}_{4}\right)_{3} \mathrm{~N}(9)$} & 276 & 1.14 & $\mathrm{Et}_{2} \mathrm{O}$ & this work \\
\hline & 282 & 1.36 & & \\
\hline \multirow[t]{3}{*}{$\left(\mathrm{Me}_{3} \mathrm{Si}\right)_{3} \mathrm{SiSiMe}_{2} \mathrm{SiMe}_{2} \mathrm{Si}\left(\mathrm{SiMe}_{3}\right)_{2} \mathrm{Si}\left(o-\mathrm{OC}_{6} \mathrm{H}_{4}\right)_{3} \mathrm{~N}(\mathbf{1 1})$} & 254 & 6.50 & $\mathrm{Et}_{2} \mathrm{O}$ & this work \\
\hline & 278 & 0.96 & & \\
\hline & 285 & 1.11 & & \\
\hline \multirow[t]{3}{*}{$\left(\mathrm{Me}_{3} \mathrm{Si}\right)_{3} \mathrm{Si}\left(\mathrm{CH}_{2}\right)_{4} \mathrm{OSi}\left[\left(\mathrm{OC}_{6} \mathrm{H}_{2} \mathrm{Me}_{2} \mathrm{CH}_{2}\right)_{3} \mathrm{~N}\right](\mathbf{1 2})$} & 225 & 2.62 & $\mathrm{Et}_{2} \mathrm{O}$ & this work \\
\hline & 273 & 0.41 & & \\
\hline & 281 & 0.38 & & \\
\hline \multirow[t]{3}{*}{$\left(\mathrm{Me}_{3} \mathrm{Si}\right)_{3} \mathrm{SiSi}\left[\left(\mathrm{OC}_{6} \mathrm{H}_{2} \mathrm{Me}_{2} \mathrm{CH}_{2}\right)_{3} \mathrm{~N}\right](13)$} & 235 & 3.66 & $\mathrm{Et}_{2} \mathrm{O}$ & this work \\
\hline & 278 & 0.62 & & \\
\hline & 287 & 0.59 & & \\
\hline
\end{tabular}

behavior of five- and six-membered chelate rings, which is not restricted by ring constraints.

Generalized structural data for 3, 6, 9, and 11-13 and several related derivatives are presented in Table 1 , where $\Delta$ is the displacement of the silatrane $\mathrm{Si}$ atom with respect to the plane formed by the equatorial $\mathrm{O}$ atoms (positive values indicate an out-of-plane displacement toward N).

It should be noted that the main dependence is evident from these data. Attachment of the bulky X group to the central Si atom results not only in $\mathrm{Si}-\mathrm{X}$ elongation in $\mathrm{X}-\mathrm{Si} \leftarrow \mathrm{N}$ but also in increased $\mathrm{Si} \leftarrow \mathrm{N}$ distances. The flexibility of the ligand framework, arising from the nonrigidity and increased size of the chelate cycles, is able to compensate steric interaction (appearing in increasing $\Delta, \mathrm{Si} \leftarrow \mathrm{N}$ distance, and $\mathrm{O}-\mathrm{Si}-\mathrm{N}-$ $\mathrm{C}$ torsion). It results in elongation of $\Delta$ with lengthening of $\mathrm{Si} \leftarrow$ $\mathrm{N} .{ }^{36}$ As was observed earlier, elongation of the $\mathrm{Si}-\mathrm{N}$ distance is connected to shifting the $\mathrm{Si}$ atom from the $\mathrm{O} 3$ plane and not to movement of the $\mathrm{N}$ atom away from this plane. At the same time, all these relationships are discussible especially due to the high impact of crystal packing effects on the structural parameters (e.g., see two different molecules for 12).

Structure in Solution. In general, the NMR spectra of hypercoordinated compounds 3-5 and 9-13 indicate that in solution, the structure corresponds to that found in a crystal. It should be noted that for 13, dynamic behavior is observed in solution. Thus, at room temperature (rt), the signals for the $\mathrm{NCH}(\mathrm{H})$ group in ${ }^{1} \mathrm{H}$ NMR appear as singlet $(\delta 3.67 \mathrm{ppm}, 6 \mathrm{H}$; fast $\mathrm{H}-\mathrm{H}$ exchange on the NMR time scale). On cooling to -40 ${ }^{\circ} \mathrm{C}$, these protons become diastereotopic $(\delta 4.44$ and $2.94 \mathrm{ppm}$, both $\mathrm{d}, J 14.5 \mathrm{~Hz}$, each $3 \mathrm{H}$ ). Apparently, this is explained by fast conformation transitions of the chelate six-membered cycles (pseudorotation with exchange of axial-equatorial protons). ${ }^{14 c, 26 c, 37}$ Crude estimation of rate constants can be obtained from these spectral data using approximate formula$\mathrm{s},{ }^{14 a}$ giving at $-40{ }^{\circ} \mathrm{C} \Delta G^{\neq} 9.2 \mathrm{kcal} / \mathrm{mol}$ with $t_{1 / 2} 0.3 \mathrm{~ms}$. In contrast to this, for 9 and 11, based on aminotrisphenol 1, a rigid structure is observed.

Comparing ${ }^{29}$ Si NMR chemical shift values (Table 2) for 35, 9-13, and several known related compounds indicates the dependence of the experimental data on the structure of the ligand used. Interaction between $\mathrm{Si}$ and $\mathrm{N}$ atoms results in upfield shifts of ${ }^{29} \mathrm{Si}$ NMR signals of the $\mathrm{SiO}_{3}$ fragment, ${ }^{22 \mathrm{a}}$ as is evident from a comparison of chemical shifts for
$\mathrm{Si}(\mathrm{OPh})_{4}$, 4, and 12. Comparing the NMR data for $\mathrm{ClSi}\left(\mathrm{OCH}_{2} \mathrm{CH}_{2}\right)_{3} \mathrm{~N}, 2$ and 5, and for 9, 11, and 13, indicates the strong dependence of chemical shift of hypercoordinated $\mathrm{Si}$ atoms from the ligand structure; the nature of the exocyclic substituent at $\mathrm{Si}$ atom $^{14 \mathrm{~b}}$ has a weaker effect. For chlorides, the transfer from trialkanolamine to aminotrisphenol backbones 1 and 2 causes an upfield shift ( -85.8 vs -97.8 vs -124.5 ppm), indicating an increasing electronic interaction among $\mathrm{O}, \mathrm{Si}$, and $\mathrm{N}$ atoms. In the corresponding potassium anions, ${ }^{22 \mathrm{a}}$ the $\mathrm{Si}-\mathrm{N}$ interaction is largely diminished, as is evident by critical downfield shift of the ${ }^{29} \mathrm{Si}$ NMR signal. The related correlation is observed for oligosilanyl hypercoordinated derivatives $\left(\mathrm{Me}_{3} \mathrm{Si}\right)_{3} \mathrm{SiSi}\left(\mathrm{OCH}_{2} \mathrm{CH}_{2}\right)_{3} \mathrm{~N}, 9$, 11, and 13. Consistent with the solid-state data, in solution, the weak $\mathrm{N} \rightarrow$ Si interaction in 9 and 11, based on aminotrisphenol 1 , causes small shielding $(-45.9 \mathrm{ppm}$ in 9$)$, whereas the strong $\mathrm{Si}-\mathrm{N}$ interaction of $\mathbf{1 3}$ is reflected by a more shielded resonance at $-107.7 \mathrm{ppm}$.

The UV-vis absorption spectra for compounds 9 and 11-13 and related $(\mathrm{MeO})_{3} \mathrm{SiSi}\left(\mathrm{SiMe}_{3}\right)_{3}(\mathbf{1 4})$ are presented in Table 3 and Figure 7.

It is known that the absorption of a trisilane unit occurs at approximately $210 \mathrm{~nm}$, and usually this band is out of registration window. Apparently, the modification of the nature of the ligand at $\mathrm{Si}(\mathrm{OR})_{3}\left(\mathrm{OMe}\right.$ vs $\left(\mathrm{OCH}_{2} \mathrm{CH}_{2}\right)_{3} \mathrm{~N}$ vs $(o-$ $\left.\mathrm{OC}_{6} \mathrm{H}_{4}\right)_{3} \mathrm{~N}$ vs $\left.\left(\mathrm{OC}_{6} \mathrm{H}_{2} \mathrm{Me}_{2} \mathrm{CH}_{2}\right)_{3} \mathrm{~N}\right)$ may affect $\mathrm{UV}-$ vis

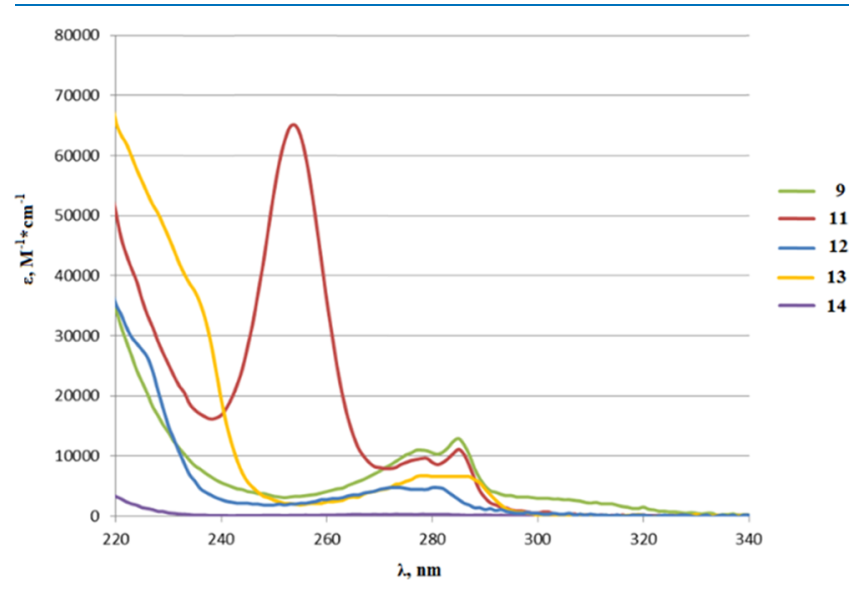

Figure 7. UV-vis absorption spectra for compounds 9 and 11-14. 
absorption and, therefore, the changing of highest occupied molecular orbital/lowest unoccupied molecular orbital levels. The effect of weakly hypercoordinated groups is insignificant, whereas the trisphenols like $\left(\mathrm{HOC}_{6} \mathrm{H}_{2} \mathrm{Me}_{2} \mathrm{CH}_{2}\right)_{3} \mathrm{~N}$ may bathochromically shift absorption bands. The band at $225 \mathrm{~nm}$ for $\mathbf{1 2}$ is caused by hypercoordinated Si atom, which is red shifted to $235 \mathrm{~nm}$ in $\mathbf{1 3}$ due to conjugation.

It is evident that the bands at $270-290 \mathrm{~nm}$ with lower absorptivity $\left(0.40-1.40 \times 10^{4}\right)$ for 9 and $\mathbf{1 1 - 1 3}$ are referred to the absorption of the aromatic groups of the ligand frameworks $\left(291 \mathrm{~nm}\right.$ for $1^{44}$ and $286 \mathrm{~nm}$ for $\left.2^{45}\right)$. The highly intensive band at $254 \mathrm{~nm}$ for 11 corresponds to the Si6 framework, and in this case, a weak hypercoordination results in weak hypsochromic shift compared to the all-methylated reference compound. ${ }^{46}$ Furthermore, the effect of hypercoordination based on aminotrisphenols with terminal modification ${ }^{17 d}$ is very weak.

\section{CONCLUSIONS}

In this work, the synthesis of a novel class of hypercoordinated silicon derivatives, oligosilanylsilatrane-like molecules, based on aminotrisphenols is presented. In contrast to previously investigated cases, high reactivity and clean reaction of silatrane-like molecules containing aromatic ligands and chloride as a leaving group were observed with silanyl anions; that is why the precise choice of the starting materials is very important. Single-crystal XRD analysis showed that $\mathrm{Si}-\mathrm{N}$ distances in catenated silatrane-like molecules with aromatic ring vary within a wide range $(2.23-2.72 \AA)$, as the nature of the ligand strongly affects the structural parameters. Apparently, the introduction of oligosilanyl substituents to the central $\mathrm{Si}$ atom in silatranes results in $\mathrm{Si}-\mathrm{N}$ bond elongation irrespective of the ligand type, which is in part explained by steric reasons, mostly due to repulsions between voluminous $\mathrm{Si}\left(\mathrm{SiMe}_{3}\right)_{2} \mathrm{R}$ fragments and rigid silatranyl- or silatranyl-like groups; the flexibility of the ligands' "arms" (which increases in the range of $o-\mathrm{C}_{6} \mathrm{H}_{4}<$ $\left.\mathrm{CH}_{2} \mathrm{CH}_{2}<\mathrm{CH}_{2}-\mathrm{o}-\mathrm{C}_{6} \mathrm{H}_{2} \mathrm{Me}_{2}\right)$ results in diminished steric impact, and, therefore, the electronic nature of the substituents gains more influence on the central $\mathrm{Si}$ geometry. NMR spectroscopy of hypercoordinated derivatives also indicates that the ${ }^{29} \mathrm{Si}$ chemical shift of $\mathrm{SiO}_{3}$ changes in wide limits $(-45$ to $-117.1 \mathrm{ppm}$ ) depending on the ligand type. Furthermore, the analysis of obtained and literature data for all groups of atranes and related derivatives indicates that the axial substituent $\mathrm{X}$ at the central $\mathrm{X}-\mathrm{SiO}_{3}$ atom strongly affects the $\mathrm{Si}-\mathrm{N}$ distance. Thus, there are three main factors influencing the structure and properties of silatranes and related compounds: nature of the ligand (formation of chelate cycles and their flexibility), geometric volumes of the substituents, and its electronic properties.

\section{EXPERIMENTAL SECTION}

General Remarks. All reactions involving air-sensitive compounds were carried out under an atmosphere of dry nitrogen or argon using either Schlenk techniques or a glovebox. Solvents were dried using a column solvent purification system. ${ }^{48}$ Potassium tert-butanolate was purchased exclusively from Merck, thionyl chloride $99.5 \%$ from Acros, and silicon tetrachloride 99\% from Riedel-de Haën.

Chemical substances used as starting materials like tris(2methoxyphenyl)amine, ${ }^{12 a}$ tris(2-hydroxy-4,6-dimethylbenzyl)amine (2), ${ }^{14 \mathrm{a}}\left(\mathrm{Me}_{3} \mathrm{Si}\right)_{3} \mathrm{SiSiMe}_{2} \mathrm{SiMe}_{2} \mathrm{Cl},{ }^{49}$ aminotris $\left(-3^{\prime}, 5^{\prime}\right.$ dimethylbenzyl-2'-oxy)silyl methoxide (4), ${ }^{14 a}$ tetrakis- (trimethylsilyl)silane, ${ }^{50}$ and $\left(\mathrm{Me}_{3} \mathrm{Si}\right)_{3} \mathrm{SiSiMe}_{2} \mathrm{SiMe}_{2} \mathrm{Cl}^{49}$ aminotris $\left(3^{\prime}, 5^{\prime}\right.$-dimethylbenzyl-2' -oxy) silyl methoxide (4), ${ }^{14 a}$ tris(trimethylsilyl)silyl potassium.THF (7), ${ }^{51}$ and tris(trimethylsilyl)silyl potassium $\cdot 18$-crown-6 $(8)^{51}$ were prepared according to literature procedures.

${ }^{1} \mathrm{H}(300 \mathrm{MHz}),{ }^{13} \mathrm{C}(75.4 \mathrm{MHz})$, and ${ }^{29} \mathrm{Si}(59.3 \mathrm{MHz}) \mathrm{NMR}$ spectra were recorded on a Varian Unity INOVA $300\left({ }^{1} \mathrm{H}\right.$ $\left.299.95 \mathrm{MHz},{ }^{13} \mathrm{C} 75.43 \mathrm{MHz},{ }^{29} \mathrm{Si} 59.59\right) \mathrm{MHz}$ spectrometer. If not noted otherwise, for all samples $\mathrm{CDCl}_{3}$ was the solvent used (the signal of residual $\mathrm{CHCl}_{3}$ has been used as a reference), or in the case of reaction samples, they were measured with a $\mathrm{D}_{2} \mathrm{O}$ capillary to provide an external lock frequency signal. ${ }^{29} \mathrm{Si} \mathrm{NMR}$ spectra were either recorded using the INEPT pulse sequence ${ }^{52}$ (optimized for $\mathrm{SiMe}_{3}$ groups), which compensates for the low isotopic abundance of ${ }^{29} \mathrm{Si}$, or using Varian standard s2pul sequence to detect the silatrane silicon signal or was used for the amplification of the signal. Elementary analysis was carried using a Heraeus Vario Elementar EL apparatus. Mass spectra were obtained with an Agilent 5975C coupled to an Agilent 7890A gas chromatograph. Assignment of peaks was based on the most abandon isotopes. Melting point determination was carried out using a melting point apparatus with a microscope from Müller Optronic equipped with a JM628 digital thermometer with a Pt100 thermocouple. UV spectra were measured on a PerkinElmer Lambda 35 spectrometer using spectroscopy-grade pentane as the solvent. Spectra plotting were done using Spectrograph 1.07.

$\mathrm{X}$-ray Structure Determination. For X-ray structure analyses, the crystals were mounted onto the tip of glass fibers, and data collection was performed with BRUKER-AXS SMART APEX and SMART APEX II CCD diffractometers using graphite-monochromated Mo $\mathrm{K} \alpha$ radiation (0.71073 $\AA$ ). The data were reduced to $F_{0}{ }^{2}$ and corrected for absorption effects with SAINT ${ }^{53}$ and SADABS ${ }^{54}$ separately. Structures were solved by direct methods and refined by the full-matrix least-squares method (SHELXL97 and SHELX2013). ${ }^{55}$ All nonhydrogen atoms were refined with anisotropic displacement parameters. Hydrogen atoms were placed in calculated positions to correspond to standard bond lengths and angles and refined using a riding model. Crystal 3 represented a pseudomerohedral twinning with domain ratio $0.678(2) / 0.322(2)$. All diagrams were drawn with $30 \%$ probability thermal ellipsoids, and all hydrogen atoms were omitted for clarity.

Crystallographic data for the structures of compounds $2 \cdot \mathrm{HCl}$, 3, 6, 9, 11, 12, and 13 (Tables S1 and S2, Supporting Information) reported in this paper have been deposited with the Cambridge Crystallographic Data Center as supplementary publication no. CCDC $1836096(2 \cdot \mathrm{HCl}), 1836095$ (3), 1836094 (6), 1836092 (9), 1836093 (11), 1836090 (12), and 1836091 (13). Copies of data can be obtained free of charge at: http://www.ccdc.cam.ac.uk/products/csd/request/. Figures of solid-state molecular structures were generated using Ortep-3 as implemented in WINGX ${ }^{56}$ and rendered using POV-Ray 3.6. ${ }^{57}$

Attention! Special caution (anhydrous conditions, hood, or drybox) should be exercised when working with chemical hazards $\left(\mathrm{KOtBu}, \mathrm{SiCl}_{4}\right.$, and $\left.\mathrm{SOCl}_{2}\right)$.

Synthesis of Compounds. Tris(2-methoxyphenyl)amine. Modified procedure was used. ${ }^{12 a}$ To a three-necked flask equipped with a reflux condenser, Dean-Stark trap, and stir bar were added $o$-anisidine $(4.96 \mathrm{~g}, 40.27 \mathrm{mmol})$, $o$-iodoanisole $(18.30 \mathrm{~g}, 78.19 \mathrm{mmol})$, powder of $\mathrm{K}_{2} \mathrm{CO}_{3}(23.50 \mathrm{~g}, 170.30$ $\mathrm{mmol})$, spongy copper powder $(5.0 \mathrm{~g})$, and nitrobenzene $(15$ $\mathrm{mL}$ ). The flask was then heated for $3 \mathrm{~h}$ at reflux with flashes of nitrogen to remove the water from the reaction mixture and 
collected in Dean-Stark trap. The reaction mixture was then cooled, and the product was extracted with hot chloroform and filtered over filter paper. Chloroform was removed by vacuum. Nitrobenzene was distilled of at $55^{\circ} \mathrm{C}, 1 \mathrm{mbar}$. The residue was dissolved in ethylacetate and mixed with $100 \mathrm{mg}$ of activated carbon and passed through a silica gel column. The used ethylacetate was removed by vacuum. The residue was dissolved in $10 \mathrm{~mL}$ of hot chloroform, and then, $5 \mathrm{~mL}$ of $n$-hexane was added and left for crystallization. Colorless crystals of tris(2methoxyphenyl)amine $(8.53 \mathrm{~g}, 65 \%)$ were obtained by filtering the solution mixture with a frit filter. mp: $152-153{ }^{\circ} \mathrm{C}$. NMR $(\delta$ in ppm): ${ }^{1} \mathrm{H}: 7.05-7.01(\mathrm{~m}, 3 \mathrm{H}$, aryl $), 6.87-6.78(\mathrm{~m}, 9 \mathrm{H}$, aryl $)$, $3.57\left(\mathrm{~s}, 9 \mathrm{H}, \mathrm{OCH}_{3}\right) \cdot{ }^{13} \mathrm{C}$ : 153.1 (aryl), 137.7 (aryl), 124.4 (aryl), 123.7 (aryl), 120.6 (aryl), 112.5 (aryl), and 55.7 (OMe).

Tris(2-hydroxyphenyl)amine (1). ${ }^{12 a}$ A mixture of tris(2methoxyphenyl)amine (1.00 g, $2.98 \mathrm{mmol}, 1.0$ equiv) and $\mathrm{AlCl}_{3}$ $(0.91 \mathrm{~g}, 6.82 \mathrm{mmol}, 2.3 \mathrm{equiv})$ in toluene $(5 \mathrm{~mL})$ was refluxed for $90 \mathrm{~min}$. After cooling the mixture to rt, $10 \% \mathrm{HCl}(20 \mathrm{~mL})$ was added, stirred for $2 \mathrm{~h}$, then extracted with EtOAc, and dried over $\mathrm{Na}_{2} \mathrm{SO}_{4}$. After the solvent was removed, $1.04 \mathrm{~g}$ of crude 1 was obtained. It was dissolved in a mixture of diethylether and pentane (1:2) and filtered. Colorless crystals of 1 (480 mg, 55\%) were obtained after recrystallization from dichloromethane. $\mathrm{mp}$ : 174-175 ${ }^{\circ} \mathrm{C}$. NMR ( $\delta$ in ppm): ${ }^{1} \mathrm{H}: 7.08$ (m, 3H, aryl), 6.946.85 (m, 9H, aryl), 5.70 (s, 3H, OH). ${ }^{13} \mathrm{C}: 149.8$ (aryl), 133.4 (aryl), 126.7 (aryl), 125.4 (aryl); 121.5 (aryl), and 117.3 (aryl).

Aminotris(phenyl-2'-oxy)silylchloride (3). A mixture of 1 (348 mg, $1.18 \mathrm{mmol}, 1.0$ equiv) and $\mathrm{SiCl}_{4}(222 \mathrm{mg}, 1.30 \mathrm{mmol}$, 1.1 equiv) in dibutylether $(5 \mathrm{~mL})$ was refluxed for $3 \mathrm{~h}$. After removal of the volatile in vacuum, a beige powder of $3(412 \mathrm{mg}$, $71 \%$ ) was obtained. mp: $270-275{ }^{\circ} \mathrm{C}$. NMR ( $\delta$ in ppm): ${ }^{1} \mathrm{H}$ : $7.82(\mathrm{~d}, 3 \mathrm{H}$, aryl), $7.25-7.20(\mathrm{~m}, 3 \mathrm{H}$, aryl $), 7.12$ (d, $3 \mathrm{H}$, aryl), $7.02\left(\mathrm{t}, 3 \mathrm{H}\right.$, aryl). ${ }^{1} \mathrm{H}$ (dimethyl sulfoxide (DMSO) $\left.-d_{6}\right): 8.41-$ $8.39(\mathrm{~m}, 3 \mathrm{H}$, aryl $), 7.26-7.25(\mathrm{~m}, 3 \mathrm{H}$, aryl $), 7.13-7.07(\mathrm{~m}, 6 \mathrm{H}$, aryl). ${ }^{13} \mathrm{C}$ (DMSO- $d_{6}$ ): 152.0 (aryl), 136.2 (aryl), 129.7 (aryl), 126.4 (aryl), 122.6 (aryl), 116.9 (aryl). ${ }^{29} \mathrm{Si}\left(\mathrm{DMSO}-d_{6}\right):-97.8$. Electron ionization (EI)/MS (70 eV) $\mathrm{m} / z$ (\%): 353 (100) $\left[\mathrm{M}^{+}\right], 337$ (3) $\left[\mathrm{M}^{+}-\mathrm{O}\right], 324(15)\left[\mathrm{SiC}_{17} \mathrm{H}_{11} \mathrm{ClNO}_{2}^{+}\right], 318$ (27) $\left[\mathrm{M}^{+}-\mathrm{Cl}\right], 300$ (3) $\left[\mathrm{SiC}_{15} \mathrm{H}_{11} \mathrm{ClNO}_{2}^{+}\right], 288$ (3) $\left[\mathrm{SiC}_{17} \mathrm{H}_{10} \mathrm{NO}_{2}^{+}\right], 261$ (15) $\left[\mathrm{SiC}_{12} \mathrm{H}_{8} \mathrm{ClNO}_{2}^{+}\right], 243$ (1) $\left[\mathrm{SiC}_{12} \mathrm{H}_{9} \mathrm{NO}_{3}{ }^{+}\right], 225$ (2) $\left[\mathrm{SiC}_{12} \mathrm{H}_{7} \mathrm{NO}_{2}{ }^{+}\right], 206$ (2) $\left[\mathrm{SiC}_{9} \mathrm{H}_{5} \mathrm{ClNO}^{+}\right], 176(3) \quad\left[\mathrm{SiC}_{5} \mathrm{H}_{7} \mathrm{ClNO}_{2}^{+}\right], 166$ (2) $\left[\mathrm{C}_{12} \mathrm{H}_{8} \mathrm{~N}^{+}\right], 153(2)\left[\mathrm{C}_{11} \mathrm{H}_{7} \mathrm{~N}^{+}\right], 139$ (2) $\left[\mathrm{C}_{10} \mathrm{H}_{5} \mathrm{~N}^{+}\right], 128$ (1) $\left[\mathrm{C}_{9} \mathrm{H}_{6} \mathrm{~N}^{+}\right], 105$ (1) $\left[\mathrm{C}_{7} \mathrm{H}_{7} \mathrm{~N}^{+}\right], 91$ (1) $\left[\mathrm{C}_{6} \mathrm{H}_{5} \mathrm{~N}^{+}\right], 77$ (3) $\left[\mathrm{C}_{6} \mathrm{H}_{5}{ }^{+}\right], 63$ (7) $\left[\mathrm{SiCl}^{+}\right]$. Elemental analysis: calcd for: $\mathrm{C}_{18} \mathrm{H}_{12} \mathrm{ClNO}_{3} \mathrm{Si}$ : C 61.10, H 3.42, N 3.96. Found: C 62.22, H 3.11, N 3.72.

Aminotris(-3',5'-dimethylbenzyl-2'-oxy)silylchloride (5). Thionyl chloride $(5.00 \mathrm{~mL}, 68.55 \mathrm{mmol})$ was added to $4(703$ $\mathrm{mg}, 1.48 \mathrm{mmol}$ ) and stirred for $20 \mathrm{~h}$. After removal of the volatile materials, compound 5 (692 mg, 69\%) was obtained as a white powder. mp: decomposition at $175{ }^{\circ} \mathrm{C}$. NMR ( $\delta$ in ppm): ${ }^{1} \mathrm{H}$ : $6.93(\mathrm{~s}, 3 \mathrm{H}$, aryl $), 6.62$ (s, 3H, aryl), 3.64 (br s, 6H, NCH $), 2.30$ (s, 9H, aryl- $\left.\mathrm{CH}_{3}\right), 2.21\left(\mathrm{~s}, 9 \mathrm{H}\right.$, aryl $\left.-\mathrm{CH}_{3}\right) .{ }^{13} \mathrm{C}: 148.0$ (aryl), 131.6 (aryl), 131.3 (aryl), 129.2 (aryl), 126.3 (aryl), 121.4 (aryl), 58.0 $\left(\mathrm{NCH}_{2}\right), 20.5$ (aryl-Me), 16.4 (aryl-Me). ${ }^{29} \mathrm{Si}$ : -124.5. EI/MS (70 eV) m/z (\%): 479 (26) $\left[\mathrm{M}^{+}\right], 463$ (2) $\left[\mathrm{SiC}_{26} \mathrm{H}_{26} \mathrm{ClNO}_{3}^{+}\right], 444$ (100) $\left[\mathrm{M}^{+}-\mathrm{Cl}\right], 360$ (2) $\left[\mathrm{SiC}_{18} \mathrm{H}_{19} \mathrm{ClNO}_{3}^{+}\right], 344$ (63) $\left[\mathrm{SiC}_{18} \mathrm{H}_{19} \mathrm{ClNO}_{2}^{+}\right], 330$ (19) $\left[\mathrm{SiC}_{17} \mathrm{H}_{17} \mathrm{ClNO}_{2}^{+}\right], 317$ (9) $\left[\mathrm{SiC}_{16} \mathrm{H}_{16} \mathrm{ClNO}_{2}^{+}\right], 309$ (5) $\left[\mathrm{SiC}_{18} \mathrm{H}_{19} \mathrm{NO}_{2}^{+}\right], 287$ (4) $\left[\mathrm{SiC}_{15} \mathrm{H}_{17} \mathrm{NO}_{3}^{+}\right], 281$ (2) $\left[\mathrm{C}_{18} \mathrm{H}_{19} \mathrm{NO}_{2}{ }^{+}\right], 237$ (3) $\left[\mathrm{SiC}_{10} \mathrm{H}_{8} \mathrm{ClNO}_{2}^{+}\right], 221$ (3) $\left[\mathrm{C}_{16} \mathrm{H}_{15} \mathrm{~N}^{+}\right], 183$ (3) $\left[\mathrm{C}_{13} \mathrm{H}_{13} \mathrm{~N}^{+}\right], 134(13)\left[\mathrm{C}_{8} \mathrm{H}_{8} \mathrm{NO}^{+}\right], 118$
(16) $\left[\mathrm{C}_{9} \mathrm{H}_{10}{ }^{+}\right], 105(10)\left[\mathrm{C}_{8} \mathrm{H}_{9}{ }^{+}\right], 77(6)\left[\mathrm{C}_{6} \mathrm{H}_{5}{ }^{+}\right]$. Elemental analysis: calcd for: $\mathrm{C}_{27} \mathrm{H}_{30} \mathrm{ClNO}_{3} \mathrm{Si}$ : C 67.55, H 6.30, N 2.92 . Found: C 66.42, H 5.70, N 2.81.

1,1,1-Aminotris(phenyl-2'-oxy)-2,2-bis(trimethylsilyl)trimethyltrisilane (9). A mixture of tetrakis(trimethylsilyl)silane (100 mg, $0.312 \mathrm{mmol}, 1.00$ equiv) and $\mathrm{KO} t \mathrm{Bu}(36 \mathrm{mg}, 0.321$ mmol, 1.03 equiv) was dissolved in THF $(1 \mathrm{~mL})$. The solution color turned orange immediately. After NMR spectroscopy confirmed the formation of oligosilylanylpotassium (7), the solvent was removed. Afterward, 7 was dissolved in toluene (2 $\mathrm{mL})$ and added dropwise over $1 \mathrm{~h}$ to a slurry of $3(110 \mathrm{mg}, 0.312$ mmol, 1.00 equiv) in toluene ( $1 \mathrm{~mL})$ under stirring. After $12 \mathrm{~h}$, the volatile was removed by vacuum and the residue was dissolved in benzene and filtered with filter paper. Colorless crystals of $9(105 \mathrm{mg}, 60 \%)$ were obtained after recrystallization from diethylether. mp: $253-257{ }^{\circ} \mathrm{C}$. NMR $(\delta$ in ppm $):{ }^{1} \mathrm{H}: 7.72$ $(\mathrm{m}, 3 \mathrm{H}$, aryl $), 7.13(\mathrm{~m}, 3 \mathrm{H}$, aryl $), 6.91(\mathrm{~m}, 6 \mathrm{H}, \operatorname{aryl}), 0.35(\mathrm{~s}$, $\left.27 \mathrm{H},\left(\mathrm{CH}_{3}\right)_{3} \mathrm{Si}\right) .{ }^{13} \mathrm{C}: 154.4$ (aryl), 136.5 (aryl), 128.6 (aryl), 127.9 (aryl), 121.9 (aryl), 118.1 (aryl), $2.2\left(\mathrm{SiMe}_{3}\right) .{ }^{29} \mathrm{Si}:-9.8$ $\left(\mathrm{Me}_{3} \mathrm{Si}\right),-46.1\left(\mathrm{SiO}_{3}\right),-135.7\left(\mathrm{Si}_{\mathrm{q}}\right)$. EI/MS $(70 \mathrm{eV}) \mathrm{m} / z(\%)$ : $565(21)\left[\mathrm{M}^{+}\right], 550(8)\left[\mathrm{M}^{+}-\mathrm{Me}\right], 492(6)\left[\mathrm{M}^{+}-\mathrm{SiMe}_{3}\right], 434$ (2) $\left[\mathrm{Si}_{4} \mathrm{C}_{20} \mathrm{H}_{20} \mathrm{NO}_{3}{ }^{+}\right], 407$ (8) $\left[\mathrm{Si}_{3} \mathrm{C}_{20} \mathrm{H}_{21} \mathrm{NO}_{3}{ }^{+}\right], 392$ (31) $\left[\mathrm{Si}_{4} \mathrm{C}_{16} \mathrm{H}_{26} \mathrm{NO}_{3}{ }^{+}\right], 376$ (14) $\left[\mathrm{Si}_{4} \mathrm{C}_{16} \mathrm{H}_{26} \mathrm{NO}_{2}^{+}\right], 335$ (5) $\left[\mathrm{Si}_{4} \mathrm{C}_{13} \mathrm{H}_{21} \mathrm{NO}_{2}^{+}\right], 318$ (100) $\left[\mathrm{SiC}_{18} \mathrm{H}_{12} \mathrm{NO}_{3}^{+}\right], 305$ (7) $\left[\mathrm{SiC}_{17} \mathrm{H}_{11} \mathrm{NO}_{3}^{+}\right], 300$ (6) $\left[\mathrm{Si}_{3} \mathrm{C}_{13} \mathrm{H}_{14} \mathrm{NO}_{2}^{+}\right], 267$ (4) $\left[\mathrm{SiC}_{14} \mathrm{H}_{9} \mathrm{NO}_{3}{ }^{+}\right], 232(73)\left[\mathrm{Si}_{4} \mathrm{C}_{8} \mathrm{H}_{24}{ }^{+}\right], 217(2)\left[\mathrm{Si}_{4} \mathrm{C}_{7} \mathrm{H}_{21}{ }^{+}\right]$, 174 (31) [ $\left.\mathrm{Si}_{3} \mathrm{C}_{6} \mathrm{H}_{18}{ }^{+}\right], 159(26)\left[\mathrm{Si}_{3} \mathrm{C}_{5} \mathrm{H}_{15}{ }^{+}\right], 131$ (15) $\left[\mathrm{C}_{8} \mathrm{H}_{5} \mathrm{NO}^{+}\right], 115(11)\left[\mathrm{C}_{8} \mathrm{H}_{5} \mathrm{~N}^{+}\right], 91(8)\left[\mathrm{C}_{6} \mathrm{H}_{5} \mathrm{~N}^{+}\right], 73(100)$ $\left[\mathrm{SiMe}_{3}{ }^{+}\right]$. UV-vis absorption $\left(\mathrm{Et}_{2} \mathrm{O}\right): \lambda 276 \mathrm{~nm}\left(\varepsilon 1.14 \times 10^{4}\right.$ $\left.\mathrm{M}^{-1} \mathrm{~cm}^{-1}\right), 282 \mathrm{~nm}\left(\varepsilon 1.14 \times 10^{4} \mathrm{M}^{-1} \mathrm{~cm}^{-1}\right)$. Elemental analysis: calcd for: $\mathrm{C}_{27} \mathrm{H}_{39} \mathrm{NO}_{3} \mathrm{Si}_{5}$ : C 57.29, H 6.94, N 2.47 . Found: C 56.95, H 6.79, N 2.50.

Bis(trimethylsilyl)silyl Potassium 18-Crown-6 [2,2',2" Nitrilotriphenoxy]silane (10). A mixture of 9 (53 mg, 0.093 mmol, 1.00 equiv), $\mathrm{KO} t \mathrm{Bu}$ ( $11 \mathrm{mg}, 0.098 \mathrm{mmol}, 1.05$ equiv), and 18-crown-6 (26 mg, $0.098 \mathrm{mmol}, 1.05$ equiv) was dissolved in $\mathrm{C}_{6} \mathrm{D}_{6}(1 \mathrm{~mL})$ and left for $14 \mathrm{~h}$. After NMR spectroscopic analysis confirmed formation of oligosilylanylpotassium, the solution mixture was left for crystallization. Compound 10 (74 $\mathrm{mg},>99 \%)$ was isolated as a red greasy substance. NMR ( $\delta$ in ppm): ${ }^{1} \mathrm{H}\left(\mathrm{C}_{6} \mathrm{D}_{6}\right): 7.43(\mathrm{~m}, 3 \mathrm{H}$, aryl $), 7.11(\mathrm{~m}, 3 \mathrm{H}$, aryl $), 6.92$ $(\mathrm{m}, 3 \mathrm{H}$, aryl $), 6.74(\mathrm{~m}, 3 \mathrm{H}$, aryl $), 0.72\left(\mathrm{~s}, 18 \mathrm{H},\left(\mathrm{CH}_{3}\right)_{3} \mathrm{Si}\right) \cdot{ }^{13} \mathrm{C}$ $\left(\mathrm{C}_{6} \mathrm{D}_{6}\right): 156.5$ (aryl), 138.8 (aryl), 131.4 (aryl), 129.3 (aryl), 126.8 (aryl), 121.2 (aryl), $7.0\left(\mathrm{SiMe}_{3}\right) .{ }^{29} \mathrm{Si}\left(\mathrm{C}_{6} \mathrm{D}_{6}\right):-3.6$ $\left(\mathrm{Me}_{3} \mathrm{Si}\right),-9.5\left(\mathrm{SiO}_{3}\right),-213.2\left(\mathrm{Si}_{\mathrm{q}}\right)$. Ethylbromide derivatization: EI/MS (70 eV) $m / z(\%): 521(21)\left[\mathrm{M}^{+}\right], 506(6)\left[\mathrm{M}^{+}-\right.$ $\mathrm{Me}], 502(3)\left[\mathrm{C}_{26} \mathrm{H}_{32} \mathrm{NO}_{2} \mathrm{Si}_{4}{ }^{+}\right], 497$ (2) $\left[\mathrm{C}_{24} \mathrm{H}_{35} \mathrm{NO}_{3} \mathrm{Si}_{4}{ }^{+}\right], 492$ (2) $\left[\mathrm{M}^{+}-\mathrm{Et}\right], 477$ (2) $\left[\mathrm{C}_{23} \mathrm{H}_{27} \mathrm{NO}_{3} \mathrm{Si}_{4}{ }^{+}\right], 448$ (14) $\left[\mathrm{C}_{23} \mathrm{H}_{26} \mathrm{NO}_{3} \mathrm{Si}_{3}{ }^{+}\right], 434$ (1) $\left[\mathrm{C}_{22} \mathrm{H}_{24} \mathrm{NO}_{3} \mathrm{Si}_{3}{ }^{+}\right], 420$ (4) $\left[\mathrm{C}_{21} \mathrm{H}_{22} \mathrm{NO}_{3} \mathrm{Si}_{3}{ }^{+}\right], 407$ (6) $\left[\mathrm{C}_{17} \mathrm{H}_{29} \mathrm{NO}_{3} \mathrm{Si}_{4}{ }^{+}\right], 404$ (5) $\left[\mathrm{C}_{20} \mathrm{H}_{18} \mathrm{NO}_{3} \mathrm{Si}_{3}{ }^{+}\right], 392$ (23) $\left[\mathrm{C}_{19} \mathrm{H}_{18} \mathrm{NO}_{3} \mathrm{Si}_{3}{ }^{+}\right], 376$ (12) $\left[\mathrm{C}_{20} \mathrm{H}_{18} \mathrm{NO}_{3} \mathrm{Si}_{2}{ }^{+}\right], 362$ (2) $\left[\mathrm{C}_{19} \mathrm{H}_{16} \mathrm{NO}_{3} \mathrm{Si}_{2}{ }^{+}\right], 346$ (2) $\left[\mathrm{C}_{18} \mathrm{H}_{12} \mathrm{NO}_{3} \mathrm{Si}_{2}{ }^{+}\right], 335$ (3) $\left[\mathrm{C}_{17} \mathrm{H}_{13} \mathrm{NO}_{3} \mathrm{Si}_{2}{ }^{+}\right], 318$ (100) $\left[\mathrm{C}_{18} \mathrm{H}_{12} \mathrm{NO}_{3} \mathrm{Si}^{+}\right], 300$ (7) $\left[\mathrm{C}_{10} \mathrm{H}_{20} \mathrm{O}_{3} \mathrm{Si}_{4}{ }^{+}\right], 264$ (5) $\left[\mathrm{C}_{7} \mathrm{H}_{20} \mathrm{O}_{3} \mathrm{Si}_{4}{ }^{+}\right], 219$ (20) $\quad\left[\mathrm{C}_{4} \mathrm{H}_{11} \mathrm{O}_{3} \mathrm{Si}_{4}{ }^{+}\right], 188$ (23) $\left[\mathrm{C}_{7} \mathrm{H}_{20} \mathrm{Si}_{3}{ }^{+}\right], 182(2)\left[\mathrm{C}_{12} \mathrm{H}_{8} \mathrm{NO}^{+}\right], 166(4)\left[\mathrm{C}_{12} \mathrm{H}_{8} \mathrm{~N}^{+}\right], 160$ (5) $\left[\mathrm{C}_{9} \mathrm{H}_{6} \mathrm{NO}_{2}^{+}\right], 154$ (1) $\left[\mathrm{C}_{11} \mathrm{H}_{8} \mathrm{~N}^{+}\right], 131$ (10) $\left[\mathrm{C}_{8} \mathrm{H}_{5} \mathrm{NO}^{+}\right]$, 119 (2) $\left[\mathrm{C}_{7} \mathrm{H}_{5} \mathrm{NO}^{+}\right], 100(3)\left[\mathrm{C}_{3} \mathrm{H}_{8} \mathrm{Si}_{2}{ }^{+}\right], 91(4)\left[\mathrm{C}_{6} \mathrm{H}_{5} \mathrm{~N}^{+}\right], 73$ (18) $\left[\mathrm{SiMe}_{3}^{+}\right], 69(23)\left[\mathrm{C}_{3} \mathrm{H}_{3} \mathrm{NO}^{+}\right]$.

$\left[\mathrm{N}\left(\mathrm{C}_{6} \mathrm{H}_{4} \mathrm{O}\right)_{3}\right] \mathrm{SiSi}\left(\mathrm{SiMe}_{3}\right)_{2} \mathrm{SiMe}_{2} \mathrm{SiMe}_{2} \mathrm{Si}\left(\mathrm{SiMe}_{3}\right)_{3}$ (11). A mixture of 9 (119 mg, $0.210 \mathrm{mmol}, 1.00$ equiv) and $\mathrm{KO} t \mathrm{Bu}(24 \mathrm{mg}$, $0.220 \mathrm{mmol}, 1.05$ equiv) was dissolved in THF ( $1 \mathrm{~mL})$. The solution color turned orange immediately. After NMR spec- 
troscopy confirmed formation of oligosilylanylpotassium reagent, the solvent was removed. Afterward, the oligosilylanylpotassium reagent obtained was dissolved in toluene $(2 \mathrm{~mL})$ and added very fast to a solution of 1-chloro-3,3-bis(trimethylsilyl)heptamethyltetrasilane $(84 \mathrm{mg}, 0.210 \mathrm{mmol}$, 1.00 equiv) in toluene $(2 \mathrm{~mL})$. After $4 \mathrm{~h}$, the solvent was removed and the residue was dissolved in $n$-pentane and filtered with filter paper. Colorless crystals of 11 (125 mg, 71\%) were obtained by crystallization from $n$-pentane at $-55^{\circ} \mathrm{C}$. $\mathrm{mp}$ : $112-$ $118^{\circ} \mathrm{C}$. NMR ( $\delta$ in ppm $):{ }^{1} \mathrm{H}\left(\mathrm{C}_{6} \mathrm{D}_{6}\right): 7.40-7.37$ (m, 3H, aryl), 7.03-7.00 (m, 3H, aryl), 6.84-6.79 (m, 3H, aryl), 6.67-6.61 (m, 3H, aryl), 0.77 (s, 6H, Si $\left.\left(\mathrm{CH}_{3}\right)_{2}\right), 0.65\left(\mathrm{~s}, 6 \mathrm{H}, \mathrm{Si}\left(\mathrm{CH}_{3}\right)_{2}\right)$, $0.54\left(\mathrm{~s}, 18 \mathrm{H},\left(\left(\mathrm{CH}_{3}\right)_{3} \mathrm{Si}\right)_{2} \mathrm{Si}\right), 0.33\left(\mathrm{~s}, 27 \mathrm{H},\left(\left(\mathrm{CH}_{3}\right)_{3} \mathrm{Si}\right)_{3} \mathrm{Si}\right) .{ }^{13} \mathrm{C}$ $\left(\mathrm{C}_{6} \mathrm{D}_{6}\right)$ : 154.5 (aryl), 137.0 (aryl), 128.9 (aryl), 128.1 (aryl), 122.4 (aryl), 118.4 (aryl), $3.7\left(\left(\mathrm{SiMe}_{3}\right)_{3} \mathrm{Si}\right), 3.3\left(\left(\mathrm{SiMe}_{3}\right)_{2} \mathrm{Si}\right)$, $1.2\left(\mathrm{SiMe}_{2}\right), 1.18\left(\mathrm{SiMe}_{2}\right) .{ }^{29} \mathrm{Si}\left(\mathrm{C}_{6} \mathrm{D}_{6}\right):-9.1\left(\left(\mathrm{Me}_{3} \mathrm{Si}\right)_{2} \mathrm{Si}\right)$, $-9.8\left(\left(\mathrm{Me}_{3} \mathrm{Si}\right)_{3} \mathrm{Si}\right),-29.7$ and $-31.1\left(\mathrm{SiMe}_{2}\right),-46.3\left(\mathrm{SiO}_{3}\right)$, -129.3 and $-130.6\left(\mathrm{Si}_{\mathrm{q}}\right)$. EI/MS $(70 \mathrm{eV}) \mathrm{m} / z(\%): 840$ (1) $\left[\mathrm{M}^{+}-\mathrm{Me}\right], 608$ (10) $\left[\mathrm{C}_{28} \mathrm{H}_{42} \mathrm{NO}_{3} \mathrm{Si}_{6}{ }^{+}\right], 550$ (57) $\left[\mathrm{C}_{26} \mathrm{H}_{36} \mathrm{NO}_{3} \mathrm{Si}_{5}{ }^{+}\right], 502(10)\left[\mathrm{C}_{20} \mathrm{H}_{32} \mathrm{NO}_{3} \mathrm{Si}_{6}{ }^{+}\right], 492$ (2) $\left[\mathrm{C}_{24} \mathrm{H}_{30} \mathrm{NO}_{3} \mathrm{Si}_{4}{ }^{+}\right], 450$ (2) $\left[\mathrm{C}_{15} \mathrm{H}_{46} \mathrm{Si}_{8}{ }^{+}\right], 414$ (7) $\left[\mathrm{C}_{17} \mathrm{H}_{24} \mathrm{NO}_{2} \mathrm{Si}_{5}{ }^{+}\right], 392$ (6) $\left[\mathrm{C}_{13} \mathrm{H}_{40} \mathrm{Si}_{7}{ }^{+}\right], 376$ (3) $\left[\mathrm{C}_{12} \mathrm{H}_{36} \mathrm{NO}_{3} \mathrm{Si}_{7}{ }^{+}\right], 318$ (14) $\left[\mathrm{C}_{18} \mathrm{H}_{12} \mathrm{NO}_{3} \mathrm{Si}^{+}\right], 264$ (15) $\left[\mathrm{C}_{16} \mathrm{H}_{10} \mathrm{NO}_{3}{ }^{+}\right], 232(3)\left[\mathrm{C}_{8} \mathrm{H}_{24} \mathrm{Si}_{4}^{+}\right], 219(59)\left[\mathrm{C}_{15} \mathrm{H}_{9} \mathrm{NO}^{+}\right]$, 173 (3) $\left[\mathrm{C}_{6} \mathrm{H}_{17} \mathrm{Si}_{3}{ }^{+}\right], 157$ (3) $\left[\mathrm{C}_{10} \mathrm{H}_{7} \mathrm{NO}^{+}\right], 131$ (34) $\left[\mathrm{C}_{8} \mathrm{H}_{5} \mathrm{NO}^{+}\right], 119(6)\left[\mathrm{C}_{7} \mathrm{H}_{5} \mathrm{NO}^{+}\right], 100(8)\left[\mathrm{C}_{3} \mathrm{H}_{8} \mathrm{Si}_{2}{ }^{+}\right], 91$ (100) $\left[\mathrm{C}_{6} \mathrm{H}_{5} \mathrm{~N}^{+}\right], 73(14)\left[\mathrm{SiMe}_{3}{ }^{+}\right], 69(66)\left[\mathrm{C}_{3} \mathrm{H}_{3} \mathrm{NO}^{+}\right]$. UVvis absorption $\left(\mathrm{Et}_{2} \mathrm{O}\right): \lambda 254 \mathrm{~nm}\left(\varepsilon 6.50 \times 10^{4} \mathrm{M}^{-1} \mathrm{~cm}^{-1}\right), 278$ $\mathrm{nm}\left(\varepsilon 0.96 \times 10^{4} \mathrm{M}^{-1} \mathrm{~cm}^{-1}\right), 285 \mathrm{~nm}\left(\varepsilon 1.11 \times 10^{4} \mathrm{M}^{-1} \mathrm{~cm}^{-1}\right)$. Elemental analysis: calcd for: $\mathrm{C}_{38} \mathrm{H}_{69} \mathrm{NO}_{3} \mathrm{Si}_{9}$ : C 51.87, $\mathrm{H} 8.12, \mathrm{~N}$ 1.63. Found: C 51.54, H 7.63, N 1.61.

1,1,1-Aminotris (-3', 5' -dimethylbenzyl-2' -oxy)-(4" -tris(trimethylsilyl)silyl)butanyl-oxysilane (12). A mixture of tetrakis(trimethylsilyl)silane $(280 \mathrm{mg}, 0.873 \mathrm{mmol}, 1.00$ equiv) and $\mathrm{KO} t \mathrm{Bu}$ (101 mg, $0.899 \mathrm{mmol}, 1.03$ equiv) was dissolved in THF $(3 \mathrm{~mL})$. The solution color turned orange immediately. After NMR spectroscopy confirmed formation of 7, THF was removed. Afterward, 7 was dissolved in toluene (5 $\mathrm{mL}$ ) and added dropwise over $10 \mathrm{~min}$ to a slurry of compound 5 (419 mg, $0.873 \mathrm{mmol}, 1.00$ equiv) in toluene ( $3 \mathrm{~mL}$ ) under stirring. After $12 \mathrm{~h}$, the volatile was removed and the residue was dissolved in benzene and filtered with filter paper. Colorless crystals of 12 ( $425 \mathrm{mg}$, 64\%) were obtained after recrystallization from a mixture of acetonitrile and diethylether (1:2). mp: 144-153 ${ }^{\circ} \mathrm{C}$. NMR ( $\delta$ in ppm): ${ }^{1} \mathrm{H}: 6.87$ (s, 3H, aryl), $6.66(\mathrm{~s}$, $3 \mathrm{H}$, aryl $), 4.14\left(\mathrm{t}, J=6.5 \mathrm{~Hz}, 2 \mathrm{H}, \mathrm{OCH}_{2}\right), 3.45\left(\mathrm{~s}, 6 \mathrm{H}, \mathrm{NCH}_{2}\right)$, 2.28 (s, 9H, aryl- $\left.\mathrm{CH}_{3}\right), 2.19\left(\mathrm{~s}, 9 \mathrm{H}\right.$, aryl- $\left.\mathrm{CH}_{3}\right), 1.79(\mathrm{~m}, 2 \mathrm{H}$, $\left.\mathrm{CH}_{2}\right), 1.57\left(\mathrm{~m}, 2 \mathrm{H}, \mathrm{CH}_{2}\right), 0.88\left(\mathrm{~m}, 2 \mathrm{H}, \mathrm{SiCH}_{2}\right), 0.17(\mathrm{~s}, 27 \mathrm{H}$, $\left.\left(\mathrm{CH}_{3}\right)_{3} \mathrm{Si}\right) .{ }^{13} \mathrm{C}$ (benzene, $\mathrm{D}_{2} \mathrm{O}$-capillary): 149.0 (aryl), 131.1 (aryl), 130.7 (aryl), 129.2 (aryl), 129.0 (aryl), 127.2 (aryl), 63.0 $\left(\mathrm{CH}_{2}\right), 56.4\left(\mathrm{NCH}_{2}\right), 37.7\left(\mathrm{CH}_{2}\right), 25.9\left(\mathrm{CH}_{2}\right), 20.2$ (aryl-Me), 17.0 (aryl-Me), $7.9\left(\mathrm{CH}_{2}\right), 1.1\left(\mathrm{Me}_{3} \mathrm{Si}-\mathrm{Si}\right) .{ }^{29} \mathrm{Si}:-12.8$ $\left(\mathrm{Me}_{3} \mathrm{Si}\right),-82.1\left(\left(\mathrm{Me}_{3} \mathrm{Si}\right)_{3} \mathrm{Si}\right),-117.1\left(\mathrm{SiO}_{3}\right) . \mathrm{EI} / \mathrm{MS}(70 \mathrm{eV})$ $m / z(\%): 763$ (2) $\left[\mathrm{M}^{+}\right], 690$ (1) $\left[\mathrm{M}^{+}-\mathrm{SiMe}_{3}\right], 628$ (37) $\left[\mathrm{Si}_{5} \mathrm{C}_{31} \mathrm{H}_{54} \mathrm{NO}_{3}{ }^{+}\right], 556(3)\left[\mathrm{Si}_{4} \mathrm{C}_{28} \mathrm{H}_{46} \mathrm{NO}_{3}{ }^{+}\right], 500(20)$ $\left[\mathrm{Si}_{3} \mathrm{C}_{25} \mathrm{H}_{38} \mathrm{NO}_{4}^{+}\right], 444(100)\left[\mathrm{SiC}_{27} \mathrm{H}_{30} \mathrm{NO}_{3}{ }^{+}\right], 417$ (4) $\left[\mathrm{Si}_{3} \mathrm{C}_{20} \mathrm{H}_{31} \mathrm{NO}_{3}{ }^{+}\right], 382(15)\left[\mathrm{Si}_{3} \mathrm{C}_{16} \mathrm{H}_{28} \mathrm{NO}_{4}^{+}\right], 326$ (5) $\left[\mathrm{SiC}_{18} \mathrm{H}_{20} \mathrm{NO}_{3}{ }^{+}\right], 263$ (4) $\left[\mathrm{Si}_{2} \mathrm{C}_{13} \mathrm{H}_{19} \mathrm{O}_{2}{ }^{+}\right], 247$ (13) $\left[\mathrm{Si}_{4} \mathrm{C}_{9} \mathrm{H}_{27}{ }^{+}\right], 231(34)\left[\mathrm{Si}_{4} \mathrm{C}_{8} \mathrm{H}_{23}{ }^{+}\right], 191(6)\left[\mathrm{SiC}_{10} \mathrm{H}_{13} \mathrm{NO}^{+}\right]$, 175 (59) $\left[\mathrm{Si}_{3} \mathrm{C}_{6} \mathrm{H}_{19}{ }^{+}\right], 147$ (7) $\left[\mathrm{SiC}_{8} \mathrm{H}_{7} \mathrm{O}^{+}\right], 131$ (22) $\left[\mathrm{C}_{8} \mathrm{H}_{5} \mathrm{NO}^{+}\right], 119(18)\left[\mathrm{C}_{8} \mathrm{H}_{7} \mathrm{O}^{+}\right], 91$ (9) $\left[\mathrm{C}_{7} \mathrm{H}_{7}^{+}\right], 73$ (93) $\left[\mathrm{SiMe}_{3}{ }^{+}\right]$. UV-vis absorption $\left(\mathrm{Et}_{2} \mathrm{O}\right): \lambda 225(\mathrm{sh}) \mathrm{nm}(\varepsilon 2.62 \times$ $\left.10^{4} \mathrm{M}^{-1} \mathrm{~cm}^{-1}\right), 273 \mathrm{~nm}\left(\varepsilon 0.41 \times 10^{4} \mathrm{M}^{-1} \mathrm{~cm}^{-1}\right), 281 \mathrm{~nm}(\varepsilon$ $\left.0.38 \times 10^{4} \mathrm{M}^{-1} \mathrm{~cm}^{-1}\right)$. Elemental analysis: calcd for: $\mathrm{C}_{40} \mathrm{H}_{65} \mathrm{NO}_{4} \mathrm{Si}_{5}$ : C 62.85, H 8.57, N 1.83. Found: C 62.84, H 8.38, N 1.92 .

1,1,1-Aminotris(-3',5'-dimethylbenzyl-2'-oxy)-2,2-bis(trimethylsilyl)trimethyltrisilane (13). A mixture of tetrakis(trimethylsilyl)silane (400 mg, $1.25 \mathrm{mmol}, 1.00$ equiv) with $\mathrm{KO}$ Bu (144 mg, $1.29 \mathrm{mmol}, 1.03$ equiv) and 18-crown-6 (340 $\mathrm{mg}, 1.29 \mathrm{mmol}, 1.03$ equiv) was dissolved in toluene $(5 \mathrm{~mL})$. After NMR spectroscopy confirmed formation of $\mathbf{8}$, this orange solution was added dropwise over $5 \mathrm{~min}$ to slurry $5(600 \mathrm{mg}$, $1.25 \mathrm{mmol}, 1.00$ equiv) in toluene $(2 \mathrm{~mL})$ under stirring. After $12 \mathrm{~h}$, the solution mixture was quenched with distilled water, the organic phase was separated, the inorganic phase was washed with toluene, and the combined organic phase was dried over $\mathrm{Na}_{2} \mathrm{SO}_{4}$. Colorless crystals of 13 (635 g, 73\%) were obtained after recrystallization from diethylether. $\mathrm{mp}: 185-190^{\circ} \mathrm{C}$. NMR $(\delta$ in ppm $):{ }^{1} \mathrm{H}\left(\right.$ at $\left.-40{ }^{\circ} \mathrm{C}\right): 6.95(\mathrm{~s}, 3 \mathrm{H}$, aryl $), 6.60(\mathrm{~s}, 3 \mathrm{H}$, aryl $)$, 4.46 (d, $\left.J=14.4 \mathrm{~Hz}, 3 \mathrm{H}, \mathrm{NCH}_{2}\right), 2.96(\mathrm{~d}, J=14.4 \mathrm{~Hz}, 3 \mathrm{H}$, $\left.\mathrm{NCH}_{2}\right), 2.27$ (s, 9H, aryl- $\left.\mathrm{CH}_{3}\right), 2.24\left(\mathrm{~s}, 9 \mathrm{H}\right.$, aryl $\left.-\mathrm{CH}_{3}\right), 0.23$ (s, $\left.27 \mathrm{H},\left(\mathrm{CH}_{3}\right)_{3} \mathrm{Si}\right) .{ }^{1} \mathrm{H}(\mathrm{rt}): 6.91(\mathrm{~s}, 3 \mathrm{H}$, aryl $), 6.57$ (s, $3 \mathrm{H}$, aryl), 3.66 (br s, 6H, $\left.\mathrm{NCH}_{2}\right), 2.28\left(\mathrm{~s}, 9 \mathrm{H}\right.$, aryl- $\left.\mathrm{CH}_{3}\right), 2.22$ (s, 9H, aryl$\left.\mathrm{CH}_{3}\right), 0.26\left(\mathrm{~s}, 27 \mathrm{H},\left(\mathrm{CH}_{3}\right)_{3} \mathrm{Si}\right) .{ }^{13} \mathrm{C}: 148.5$ (aryl), 130.9 (aryl), 129.6 (aryl), 127.4 (aryl), 125.8 (aryl), 119.8 (aryl), 57.9 $\left(\mathrm{NCH}_{2}\right), 20.5$ (aryl-Me), 17.9 (aryl-Me), $4.4\left(\mathrm{Me}_{3} \mathrm{Si}-\mathrm{Si}\right) .{ }^{29} \mathrm{Si}$ : $-10.4\left(\mathrm{Me}_{3} \mathrm{Si}\right),-107.7\left(\mathrm{SiO}_{3}\right),-123.6\left(\left(\mathrm{Me}_{3} \mathrm{Si}\right)_{3} \mathrm{Si}\right) . \mathrm{EI} / \mathrm{MS}$ $(70 \mathrm{eV}) \mathrm{m} / z(\%): 676(1)\left[\mathrm{M}^{+}-\mathrm{Me}\right], 557$ (21) $\left[\mathrm{Si}_{5} \mathrm{C}_{27} \mathrm{H}_{47} \mathrm{NO}_{2}^{+}\right], \quad 542$ (14) $\left[\mathrm{Si}_{5} \mathrm{C}_{26} \mathrm{H}_{44} \mathrm{NO}_{2}^{+}\right], 484$ (55) $\left[\mathrm{Si}_{4} \mathrm{C}_{24} \mathrm{H}_{38} \mathrm{NO}_{2}^{+}\right], 444$ (100) $\left[\mathrm{SiC}_{27} \mathrm{H}_{30} \mathrm{NO}_{3}{ }^{+}\right], 410$ (7) $\left[\mathrm{Si}_{3} \mathrm{C}_{20} \mathrm{H}_{24} \mathrm{NO}_{3}{ }^{+}\right], 382$ (31) $\left[\mathrm{Si}_{4} \mathrm{C}_{16} \mathrm{H}_{32} \mathrm{NO}_{2}^{+}\right], 366$ (3) $\left[\mathrm{Si}_{4} \mathrm{C}_{15} \mathrm{H}_{28} \mathrm{NO}_{2}^{+}\right], 352$ (4) $\left[\mathrm{Si}_{4} \mathrm{C}_{14} \mathrm{H}_{26} \mathrm{NO}_{2}^{+}\right], 322$ (15) $\left[\mathrm{Si}_{4} \mathrm{C}_{13} \mathrm{H}_{24} \mathrm{NO}^{+}\right], 310$ (21) $\left[\mathrm{SiC}_{18} \mathrm{H}_{20} \mathrm{NO}_{2}^{+}\right], 292$ (6) $\left[\mathrm{Si}_{5} \mathrm{C}_{9} \mathrm{H}_{28} \mathrm{O}^{+}\right], 248(4)\left[\mathrm{Si}_{4} \mathrm{C}_{9} \mathrm{H}_{28}{ }^{+}\right], 235(6)\left[\mathrm{Si}_{4} \mathrm{C}_{6} \mathrm{H}_{19} \mathrm{O}_{2}{ }^{+}\right.$, , 221 (6) $\left[\mathrm{SiC}_{10} \mathrm{H}_{11} \mathrm{NO}_{3}{ }^{+}\right], 207(6)\left[\mathrm{SiC}_{9} \mathrm{H}_{9} \mathrm{NO}_{3}{ }^{+}\right], 174(15)$ $\left[\mathrm{Si}_{3} \mathrm{C}_{6} \mathrm{H}_{18}{ }^{+}\right], 159(10)\left[\mathrm{Si}_{3} \mathrm{C}_{5} \mathrm{H}_{15}{ }^{+}\right], 134(43)\left[\mathrm{C}_{9} \mathrm{H}_{10} \mathrm{O}^{+}\right], 119$ (9) $\left[\mathrm{C}_{8} \mathrm{H}_{7} \mathrm{O}^{+}\right], 105(19)\left[\mathrm{C}_{7} \mathrm{H}_{5} \mathrm{O}^{+}\right], 73(80)\left[\mathrm{SiMe}_{3}{ }^{+}\right]$. UV-vis absorption $\left(\mathrm{Et}_{2} \mathrm{O}\right): \lambda 235(\mathrm{sh}) \mathrm{nm}\left(\varepsilon 3.66 \times 10^{4} \mathrm{M}^{-1} \mathrm{~cm}^{-1}\right), 278$ $\mathrm{nm}\left(\varepsilon 0.62 \times 10^{4} \mathrm{M}^{-1} \mathrm{~cm}^{-1}\right), 287 \mathrm{~nm}\left(\varepsilon 0.59 \times 10^{4} \mathrm{M}^{-1} \mathrm{~cm}^{-1}\right)$. Elemental analysis: calcd for: $\mathrm{C}_{36} \mathrm{H}_{57} \mathrm{NO}_{3} \mathrm{Si}_{5}: \mathrm{C} 62.46, \mathrm{H} 8.30, \mathrm{~N}$ 2.02. Found: C 61.52, H 8.14, N 2.11.

Solid-State DFT. Solid-state DFT computations were performed in the CRYSTAL0 $9^{58}$ software package using the B3LYP functional with all-electron Gaussian-type orbital basis set $6-31 \mathrm{G}^{* *}$. 88-31G* basis set was used for $\mathrm{Si}^{59}$ London dispersion interactions were taken into account by using the semiempirical D2 scheme. ${ }^{60}$ The periodic structures with the experimental atomic positions were used. ${ }^{61}$ The Bader analysis of the periodic electron density ${ }^{62}$ obtained from the crystalline wave function was performed with TOPOND. ${ }^{63}$ The energy of the particular noncovalent interaction $E_{\text {int }}$ was estimated as ${ }^{64} E_{\text {int }}$ $=0.429 \cdot G_{\mathrm{b}}$ (in atomic units). $G_{\mathrm{b}}$ is the positively defined local electronic kinetic energy density at the bond critical point.

\section{ASSOCIATED CONTENT}

\section{Supporting Information}

The Supporting Information is available free of charge on the ACS Publications website at DOI: 10.1021/acsomega.8b01402.

Crystallographic information, NMR spectra $\left({ }^{1} \mathrm{H},{ }^{13} \mathrm{C}\right.$,

${ }^{29} \mathrm{Si}$ ) of the compounds obtained (PDF)

Crystallographic data for compounds $2 \cdot \mathrm{HCl}, 3,6,9$, and

11-13 (CIF)

Calculated structures (XYZ) 


\section{AUTHOR INFORMATION}

\section{Corresponding Authors}

*E-mail: zaitsev@org.chem.msu.ru (K.V.Z.).

*E-mail: christoph.marschner@tugraz.at (C.M.).

\section{ORCID}

Kirill V. Zaitsev: 0000-0003-3106-8692

Andrei V. Churakov: 0000-0003-3336-4022

Judith Baumgartner: 0000-0002-9938-1813

Christoph Marschner: 0000-0001-8586-2889

\section{Notes}

The authors declare no competing financial interest.

\section{ACKNOWLEDGMENTS}

This work was supported in part by M.V. Lomonosov Moscow State University Program of Development as well as by the Austrian Science Fund (FWF) (project P 26417). Part of the Xray diffraction studies was performed at the Centre of Shared Equipment within the State Assignment on Fundamental Research to IGIC RAS.

\section{REFERENCES}

(1) (a) Jurkschat, K.; Tzschach, A.; Muegge, C.; Piret-Meunier, J.; Van Meerssche, M.; Van Binst, G.; Wynants, C.; Gielen, M.; Willem, R. Molecular structure of and restricted internal rotation about the tin-tin bond in $\left[\mathrm{ClSn}\left(\mathrm{CH}_{2} \mathrm{CH}_{2} \mathrm{CH}_{2}\right)_{2} \mathrm{NCH}_{3}\right]_{2}$ and solution isomerism and isomerizations in $\left[\mathrm{CH}_{3} \mathrm{Sn}\left(\mathrm{CH}_{2} \mathrm{CH}_{2} \mathrm{CH}_{2}\right)_{2} \mathrm{NCH}_{3}\right]_{2}$, two compounds with five-coordinate tin centers bound to each other. Organometallics 1988, 7, 593-603. (b) Miller, R. D.; Michl, J. Polysilane high polymers. Chem. Rev. 1989, 89, 1359-1410. (c) Fischer, J.; Baumgartner, J.; Marschner, C. Synthesis and Structure of Sila-Adamantane. Science 2005, 310, 825. (d) Amadoruge, M. L.; Weinert, C. S. Singly Bonded Catenated Germanes: Eighty Years of Progress. Chem. Rev. 2008, 108, 4253-4294. (e) Marschner, C. Oligosilanes. In Functional Molecular Silicon Compounds I. Structure and Bonding; Scheschkewitz, D., Ed.; Springer International Publishing, 2014; Vol. 155, pp 163-228. (f) Zaitsev, K. V.; Churakov, A. V.; Poleshchuk, O. K.; Oprunenko, Y. F.; Zaitseva, G. S.; Karlov, S. S. New oligogermane with a five coordinate germanium atom: the preparation of 1-germylgermatrane. Dalton Trans. 2014, 43, 6605-6609.

(2) (a) Pestunovich, V.; Kirpichenko, S.; Voronkov, M. Silatranes and Their Tricyclic Analogs. In The Chemistry of Organic Silicon Compounds; Rappoport, Z., Apeloig, Y., Eds.; Wiley: Chichester, U.K., 2003; pp 1447-1537. (b) Kano, N. Penta- and Hexacoordinated Silicon(IV) Compounds. Organosilicon Compounds; Elsevier Inc., 2017; pp 645716.

(3) Marro, E. A.; Press, E. M.; Siegler, M. A.; Klausen, R. S. Directional Building Blocks Determine Linear and Cyclic Silicon Architectures. J. Am. Chem. Soc. 2018, 5976-5986.

(4) (a) Voronkov, M. G.; Dyakov, V. M.; Kirpichenko, S. V. Silatranes. J. Organomet. Chem. 1982, 233, 1-147. (b) Verkade, J. G. Atranes: new examples with unexpected properties. Acc. Chem. Res. 1993, 26, 483489. (c) Verkade, J. G. Main group atranes: chemical and structural features. Coord. Chem. Rev. 1994, 137, 233-295. (d) Karlov, S. S.; Zaitseva, G. S. Germatranes and their Analogs. Synthesis, Structure, and Reactivity (Review). Chem. Heterocycl. Compd. 2001, 37, 1325-1357. (e) Puri, J. K.; Singh, R.; Chahal, V. K. Silatranes: a review on their synthesis, structure, reactivity and applications. Chem. Soc. Rev. 2011, 40, 1791-1840. (f) Singh, G.; Kaur, G.; Singh, J. Progressions in hypercoordinate silicon complexes. Inorg. Chem. Commun. 2018, 88, 11-20.

(5) (a) Riggleman, S.; De Shong, P. Application of Silicon-Based Cross-Coupling Technology to Triflates. J. Org. Chem. 2003, 68, 81068109. (b) Pidaparthi, R. R.; Welker, M. E.; Day, C. S.; Wright, M. W. Preparation of 2-Trialkylsiloxy-Substituted 1,3-Dienes and Their Diels-Alder/Cross-Coupling Reactions. Org. Lett. 2007, 9, 16231626. (c) Skrypai, V.; Hurley, J. J. M.; Adler, M.J. Silatrane as a Practical and Selective Reagent for the Reduction of Aryl Aldehydes to Benzylic Alcohols. Eur. J. Org. Chem. 2016, 2207-2211.

(6) (a) Black, C. A.; Ucci, J. W.; Vorpagel, J. S.; Mauck, M. C.; Fenlon, E. E. Stereoselective and improved syntheses and anticancer testing of 3'-O-silatranylthymidines. Bioorg. Med. Chem. Lett. 2002, 12, 35213523. (b) Voronkov, M. G.; Baryshok, V. P. Antitumor Activity of Silatranes (A Review). Pharm. Chem. J. 2004, 38, 3-9. (c) Lyubchenko, Y. L.; Shlyakhtenko, L. S.; Gall, A. A. Atomic Force Microscopy Imaging and Probing of DNA, Proteins, and Protein-DNA Complexes: Silatrane Surface Chemistry. In DNA-Protein Interactions; Leblanc, B., Moss, T., Eds.; Methods in Molecular Biology (Methods and Protocols); Humana Press, 2009; Vol. 543, pp 337-351. (d) Singh, G.; Saroa, A.; Girdhar, S.; Rani, S.; Choquesillo-Lazarte, D.; Sahoo, S. C. Incorporation of azo group at axial position of silatranes: synthesis, characterization and antimicrobial activity. Appl. Organomet. Chem. 2015, 29, 549-555. (e) Singh, G.; Arora, A.; Mangat, S. S.; Rani, S.; Kaur, H.; Goyal, K.; Sehgal, R.; Maurya, I. K.; Tewari, R.; ChoquesilloLazarte, D.; Sahoo, S.; Kaur, N. Design, synthesis and biological evaluation of chalconyl blended triazole allied organosilatranes as giardicidal and trichomonacidal agents. Eur. J. Med. Chem. 2016, 108, 287-300. (f) Singh, G.; Rani, S.; Gawri, S.; Sinha, S.; Sehgal, R. Adamantylated organosilatranes: design, synthesis, and potential appraisal in surface modification and anti-protozoal activity. New J. Chem. 2017, 41, 11626-11639. (g) Ramesh, R.; Reddy, D. S. Quest for Novel Chemical Entities through Incorporation of Silicon in Drug Scaffolds. J. Med. Chem. 2018, 3779-3798.

(7) (a) Casasús, R.; Climent, E.; Marcos, M. D.; Martínez-Máñez, R.; Sancenón, F.; Soto, J.; Amorós, P.; Cano, J.; Ruiz, E. Dual Aperture Control on $\mathrm{pH}$ - and Anion-Driven Supramolecular Nanoscopic Hybrid Gate-like Ensembles. J. Am. Chem. Soc. 2008, 130, 1903-1917. (b) Phiriyawirut, P.; Magaraphan, R.; Jamieson, A. M.; Wongkasemjit, S. MFI zeolite synthesis directly from silatrane via sol-gel process and microwave technique. Mater. Sci. Eng., A 2003, 361, 147-154.

(8) (a) Shlyakhtenko, L. S.; Gall, A. A.; Filonov, A.; Cerovac, Z.; Lushnikov, A.; Lyubchenko, Y. L. Silatrane-based surface chemistry for immobilization of DNA, protein-DNA complexes and other biological materials. Ultramicroscopy 2003, 97, 279-287. (b) Utchariyajit, K.; Wongkasemjit, S. Effect of synthesis parameters on mesoporous SAPO5 with AFI-type formation via microwave radiation using alumatrane and silatrane precursors. Microporous Mesoporous Mater. 2010, 135, $116-123$.

(9) (a) Warncke, G.; Böhme, U.; Günther, B.; Kronstein, M. Racemization versus retention of chiral information during the formation of silicon and tin complexes with chiral Schiff base ligands. Polyhedron 2012, 47, 46-52. (b) Seiler, O.; Burschka, C.; Fenske, T.; Troegel, D.; Tacke, R. Neutral Hexa- and Pentacoordinate Silicon(IV) Complexes with $\mathrm{SiO}_{6}$ and $\mathrm{SiO}_{4} \mathrm{~N}$ Skeletons. Inorg. Chem. 2007, 46, 5419-5424. (c) Kämpfe, A.; Kroke, E.; Wagler, J. Hypercoordinate Silicon Complexes of $\left(\mathrm{O}, \mathrm{N}, \mathrm{N}^{\prime}\right.$ vs. $\left.\mathrm{O}, \mathrm{N}, \mathrm{O}^{\prime}\right)$ Schiff Base Type $\mathrm{N}$-(2Carbamidophenyl)imines: Examples of Exclusively O-Silylated Carbamides. Eur. J. Inorg. Chem. 2009, 1027-1035. (d) Weiß, J.; Sinner, K.; Baus, J. A.; Burschka, C.; Tacke, R. Neutral Hexacoordinate Silicon(IV) Complexes with a $\mathrm{SiO}_{4} \mathrm{NC}$ or $\mathrm{SiO}_{3} \mathrm{~N}_{2} \mathrm{C}$ Skeleton and Neutral Pentacoordinate Silicon(IV) Complexes Containing a Trianionic Tetradentate O,N,O,O Ligand. Eur. J. Inorg. Chem. 2014, 475-483.

(10) Böhme, U.; Wiesner, S.; Günther, B. Easy access to chiral pentaand hexacoordinate silicon compounds. Inorg. Chem. Commun. 2006, 9, 806-809.

(11) (a) Wagler, J.; Roewer, G. First X-ray Structures of Ethylene Bridged Neutral Dimeric Hexacoordinate Silicon Complexes with Tetradentate Salen-Type Ligands. Z. Naturforsch., B: J. Chem. Sci. 2005, 60, 709-714. (b) Wagler, J.; Böhme, U.; Brendler, E.; Thomas, B.; Goutal, S.; Mayr, H.; Kempf, B.; Remennikov, G. Y.; Roewer, G. Switching between penta- and hexacoordination with salen-siliconcomplexes. Inorg. Chim. Acta 2005, 358, 4270-4286.

(12) (a) Frye, C. L.; Vincent, G. A.; Hauschildt, G. L. Pentacoordinate Silicon Derivatives. III.1 2,2'2'-Nitrilotriphenol, a New Chelating Agent. J. Am. Chem. Soc. 1966, 88, 2727-2730. (b) Boer, F. P.; Turley, J. W.; Flynn, J. J. Structural studies of pentacoordinate silicon. II. 
Phenyl(2'2',2"-nitrilotriphenoxy)silane. J. Am. Chem. Soc. 1968, 90, $5102-5105$.

(13) Kemme, A.; Bleidelis, J.; Zelchan, I. S. G.; Lukevics, E. 2,9,10Trioxa-6-aza-1-silatricyclo[4,3,3,01,6] dodecane. A novel heterocyclic system: synthesis, X-ray crystal and molecular structure of the 1chloromethyl derivative. J. Chem. Soc., Chem. Commun. 1976, 10411042.

(14) (a) Chandrasekaran, A.; Day, R. O.; Holmes, R. R. A New Class of Silatranes: Structure and Dynamic NMR Behavior. J. Am. Chem. Soc. 2000, 122, 1066-1072. (b) Timosheva, N. V.; Chandrasekaran, A.; Day, R. O.; Holmes, R. R. Synthesis of Trioxy- and Tetraoxysilatranes with All Six-Membered Rings. Structure and Dynamic NMR Behavior. Organometallics 2000, 19, 5614-5622. (c) Timosheva, N. V.; Chandrasekaran, A.; Day, R. O.; Holmes, R. R. Synthesis of Silatranes with All Six-Membered Rings. Influence of Steric Effect on Structure and NMR Behavior. Organometallics 2001, 20, 2331-2337.

(15) Srivastav, N.; Mutneja, R.; Singh, N.; Singh, R.; Kaur, V.; Wagler, J.; Kroke, E. Diverse Molecular Architectures of Si and Sn [4.4.3.01,6]Tridecane Cages Derived from a Mannich Base Possessing Semi-Rigid Unsymmetrical Podands. Eur. J. Inorg. Chem. 2016, 1730-1737.

(16) (a) El-Sayed, I.; Hatanaka, Y.; Muguruma, C.; Shimada, S.; Tanaka, M.; Koga, N.; Mikami, M. Synthesis, X-ray Structure, and Electronic Properties of Oligosilanes Containing Pentacoordinate Silicon Moieties at Internal Positions. J. Am. Chem. Soc. 1999, 121, 5095-5096. (b) El-Sayed, I.; Hatanaka, Y.; Onozawa, S.-y.; Tanaka, M. Unusual Locking of Silicon Chains into all-transoid Conformation by Pentacoordinate Silicon Atoms. J. Am. Chem. Soc. 2001, 123, 35973598.

(17) (a) Roewe, K. D.; Rheingold, A. L.; Weinert, C. S. A luminescent and dichroic hexagermane. Chem. Commun. 2013, 49, 8380-8382. (b) Zaitsev, K. V.; Lermontova, E. K.; Churakov, A. V.; Tafeenko, V. A.; Tarasevich, B. N.; Poleshchuk, O. K.; Kharcheva, A. V.; Magdesieva, T. V.; Nikitin, O. M.; Zaitseva, G. S.; Karlov, S. S. Compounds of Group 14 Elements with an Element-Element $(\mathrm{E}=\mathrm{Si}, \mathrm{Ge}, \mathrm{Sn})$ Bond: Effect of the Nature of the Element Atom. Organometallics 2015, 34, 27652774. (c) Zaitsev, K. V.; Lam, K.; Zhanabil, Z.; Suleimen, Y.; Kharcheva, A. V.; Tafeenko, V. A.; Oprunenko, Y. F.; Poleshchuk, O. K.; Lermontova, E. K.; Churakov, A. V. Oligogermanes Containing Only Electron-Withdrawing Substituents: Synthesis and Properties. Organometallics 2017, 36, 298-309. (d) Zaitsev, K. V.; Lam, K.; Poleshchuk, O. K.; Kuz'mina, L. G.; Churakov, A. V. Oligothienyl catenated germanes and silanes: synthesis, structure, and properties. Dalton Trans. 2018, 47, 5431-5444. (e) Zaitsev, K. V.; Kharcheva, A. V.; Lam, K.; Zhanabil, Z.; Issabayeva, G.; Oprunenko, Y. F.; Churakov, A. V.; Zaitseva, G. S.; Karlov, S. S. Donor-acceptor molecular oligogermanes: Novel properties and structural aspects. J. Organomet. Chem. 2018, 867, 228-237.

(18) Zaitsev, K. V.; Tafeenko, V. A.; Oprunenko, Y. F.; Kharcheva, A. V.; Zhanabil, Z.; Suleimen, Y.; Lam, K.; Zaitsev, V. B.; Zaitseva, A. V.; Zaitseva, G. S.; Karlov, S. S. Molecular Oligogermanes and Related Compounds: Structure, Optical and Semiconductor Properties. Chem. - Asian J. 2017, 12, 1240-1249.

(19) (a) Yamamoto, Y.; Matsubara, H.; Murakami, K.; Yorimitsu, H.; Osuka, A. Activator-Free Palladium-Catalyzed Silylation of Aryl Chlorides with Silylsilatranes. Chem. - Asian J. 2015, 10, 219-224. (b) Guo, J.-D.; Sasamori, T.; Yamamoto, Y.; Matsubara, H.; Nagase, S.; Yorimitsu, H. Computational Picture of Silyl Transfer from Silylsilatranes to Arylpalladium Chloride. Bull. Chem. Soc. Jpn. 2016, 89, 192-194.

(20) Wagler, J. A Disilane with a Hypercoordinate Silicon Atom: Coordination of an Imine Ligand versus $\mathrm{Si}-\mathrm{Si}$ Bond Splitting. Organometallics 2007, 26, 155-159.

(21) Grobe, J.; Henkel, G.; Krebs, B.; Voulgarakis, N. Atran-analoge Verbindungen des Typs/Atrane Analogous Compounds of the Type. $Z$. Naturforsch., B: J. Chem. Sci. 1984, 39, 341-351.

(22) (a) Aghazadeh Meshgi, M.; Baumgartner, J.; Marschner, C. Oligosilanylsilatranes. Organometallics 2015, 34, 3721-3731. (b) Aghazadeh Meshgi, M.; Baumgartner, J.; Jouikov, V. V.; Marschner, C. Electron Transfer and Modification of Oligosilanylsilatranes and
Related Derivatives. Organometallics 2017, 36, 342-351. (c) Aghazadeh Meshgi, M.; Zitz, R.; Walewska, M.; Baumgartner, J.; Marschner, C. Tuning the $\mathrm{Si}-\mathrm{N}$ Interaction in Metalated Oligosilanylsilatranes. Organometallics 2017, 36, 1365-1371.

(23) Zaitsev, K. V.; Kapranov, A. A.; Oprunenko, Y. F.; Churakov, A. V.; Howard, J. A. K.; Tarasevich, B. N.; Karlov, S. S.; Zaitseva, G. S. Reaction of germanes and digermanes with triflic acid: The route to novel organooligogermanes. J. Organomet. Chem. 2012, 700, 207-213.

(24) Zitz, R.; Hlina, J.; Aghazadeh Meshgi, M.; Krenn, H.; Marschner, C.; Szilvási, T.; Baumgartner, J. Using Functionalized Silyl Ligands To Suppress Solvent Coordination to Silyl Lanthanide(II) Complexes. Inorg. Chem. 2017, 56, 5328-5341.

(25) Szpakolski, K.; Latham, K.; Rix, C.; Rani, R. A.; Kalantar-zadeh, $\mathrm{K}$. Silane: A new linker for chromophores in dye-sensitised solar cells. Polyhedron 2013, 52, 719-732.

(26) (a) Holmes, R. R. Comparison of Phosphorus and Silicon: Hypervalency, Stereochemistry, and Reactivity. Chem. Rev. 1996, 96, 927-950. (b) Voronkov, M. G.; Toryashinova, D.-S. D.; Baryshok, V. P.; Shainyan, B. A.; Brodskaya, É. I. Kinetics of hydrolysis of silatranes in a neutral medium. Bull. Acad. Sci. USSR, Div. Chem. Sci. (Engl. Transl.) 1984, 33, 2447-2450. (c) Chandrasekaran, A.; Day, R. O.; Holmes, R. R. Structural Influence of a Sulfonyl Group in Eight-Membered Rings of Diorganosilanes1. Organometallics 1996, 15, 3189-3197.

(27) Kemme, A. A.; Bleidelis, Y. Y.; Pestunovich, V. A.; Barishok, V. P.; Voronkov, M. G. Molecular Structure of 1-Chlorosilatrane and Some Features of the Structure of Silatranes. Dokl. Akad. Nauk SSSR 1978, 243, 688-691.

(28) Frank, D.; Baumgartner, J.; Marschner, C. First successful reaction of a silyl anion with hafnium tetrachloride. Chem. Commun. 2002, 1190-1191.

(29) Denmark, S. E.; Beutner, G. L. Lewis Base Catalysis in Organic Synthesis. Angew. Chem., Int. Ed. 2008, 47, 1560-1638.

(30) (a) Denmark, S. E.; Jacobs, R. T.; Dai-Ho, G.; Wilson, S. Synthesis, structure, and reactivity of an organogermanium Lewis acid. Organometallics 1990, 9, 3015-3019. (b) Myers, A. G.; Kephart, S. E.; Chen, H. Silicon-directed aldol reactions. Rate acceleration by small rings. J. Am. Chem. Soc. 1992, 114, 7922-7923. (c) Denmark, S. E.; Griedel, B. D.; Coe, D. M.; Schnute, M. E. Chemistry of Enoxysilacyclobutanes: Highly Selective Uncatalyzed Aldol Additions. J. Am. Chem. Soc. 1994, 116, 7026-7043. (d) Kinnaird, J. W. A.; Ng, P. Y.; Kubota, K.; Wang, X.; Leighton, J. L. Strained Silacycles in Organic Synthesis: A New Reagent for the Enantioselective Allylation of Aldehydes. J. Am. Chem. Soc. 2002, 124, 7920-7921.

(31) Groom, C. R.; Bruno, I. J.; Lightfoot, M. P.; Ward, S. C. The Cambridge Structural Database. Acta Crystallogr., Sect. B: Struct. Sci., Cryst. Eng. Mater. 2016, 72, 171-179.

(32) Garant, R. J.; Daniels, L. M.; Das, S. K.; Janakiraman, M. N.; Jacobson, R. A.; Verkade, J. G. Lewis basicity of silatranes and the molecular structures of EtOSi $\left(\mathrm{OCH}_{2} \mathrm{CH}_{2}\right)_{3} \mathrm{~N}, \mathrm{Me}_{2} \mathrm{O}^{+} \mathrm{Si}$ $\left(\mathrm{OCH}_{2} \mathrm{CH}_{2}\right)_{3} \mathrm{~N}$, and $\mathrm{CF}_{3} \mathrm{CO}_{2}$ H.cntdot.EtOSi $\left(\mathrm{OCH}_{2} \mathrm{CH}_{2}\right)_{3} \mathrm{~N}$. J. Am. Chem. Soc. 1991, 113, 5728-5735.

(33) (a) Day, R. O.; Prakasha, T. K.; Holmes, R. R.; Eckert, H. Cyclic Silanes. Sulfur-Induced Pentacoordination in a Disiloxane. Organometallics 1994, 13, 1285-1293. (b) Day, R. O.; Prakasha, T. K.; Holmes, R. R.; Eckert, H. Cyclic Silanes. Sulfur-induced Pentacoordination in a Disiloxane. Phosphorus, Sulfur Silicon Relat. Elem. 1995, 100, 211-229. (c) Tacke, R.; Burschka, C.; Richter, I.; Wagner, B.; Willeke, R. Pentacoordinate Silicon Compounds with $\mathrm{SiO}_{5}$ Skeletons Containing $\mathrm{SiOH}$ or SiOSi Groups: Derivatives of the Pentahydroxosilicate $(1-)$ Anion $\left[\mathrm{Si}(\mathrm{OH})_{5}\right]-$ and Its Anhydride $\left[(\mathrm{HO})_{4} \mathrm{Si}-\mathrm{O}-\right.$ $\left.\mathrm{Si}(\mathrm{OH})_{4}\right]_{2}$. J. Am. Chem. Soc. 2000, 122, 8480-8485.

(34) Gordon, M. S.; Carroll, M. T.; Jensen, J. H.; Davis, L. P.; Burggraf, L. W.; Guidry, R. M. Nature of the silicon-nitrogen bond in silatranes. Organometallics 1991, 10, 2657-2660.

(35) (a) Belyakov, S.; Ignatovich, L.; Lukevics, E. Concerning the transannular bond in silatranes and germatranes: a quantum chemical study. J. Organomet. Chem. 1999, 577, 205-210. (b) Schmidt, M. W.; Windus, T. L.; Gordon, M. S. Structural Trends in Silicon Atranes. J. Am. Chem. Soc. 1995, 117, 7480-7486. 
(36) Greenberg, A.; Wu, G. Structural relationships in silatrane molecules. Struct. Chem. 1990, 1, 79-85.

(37) Burke, L. P.; DeBellis, A. D.; Fuhrer, H.; Meier, H.; Pastor, S. D.; Rihs, G.; Rist, G.; Rodebaugh, R. K.; Shum, S. P. Steric Consequences on the Conformation of Medium-Sized Rings: Solution NMR, SolidState Crystallographic, ab Initio Molecular Orbital Calculations, and Molecular Mechanics Studies on Substituted Eight-Membered Organosilicon Ring Systems1. J. Am. Chem. Soc. 1997, 119, 8313-8323.

(38) Spomer, N.; Holl, S.; Zherytsyna, L.; Maysamy, F.; Frost, A.; Auner, N. Amorphous Silicon: New Insights into an Old Material. Chem. - Eur. J. 2015, 21, 5600-5616.

(39) Maringgele, W.; Meller, A. Umsetzung von Lithiiertem 2Hydroxybiphenyl Bzw. 2'-Hydroxy-Mterphenyl Mit Halogenverbindungen von Silicium und Germanium, Phosphor und Arsen. Phosphorus, Sulfur Silicon Relat. Elem. 1994, 90, 235-241.

(40) Iwamiya, J. H.; Maciel, G. E. Chemical shifts in silatrane and its derivatives: a study of the transannular interaction. J. Am. Chem. Soc. 1993, 115, 6835-6842.

(41) Bellama, J. M.; Nies, J. D.; Ben-Zvi, N. Nuclear magnetic resonance study of selected derivatives of 2,8,9-trioxa-5-aza-1silatricyclo[3.3.3.01,5] undecane (silatrane). Magn. Reson. Chem. 1986, 24, 748-753.

(42) Lazareva, N. F.; Pestunovich, V. A. Reactions of 1-hydro-and 1halosilatranes with metal salts. Russ. Chem. Bull. 2006, 55, 751-752.

(43) Sidorkin, V. F.; Pestunovich, V. A.; Voronkov, M. G. Origin of the shielding effect in the 29Si NMR spectra of silatranes. Magn. Reson. Chem. 1985, 23, 491-493.

(44) Timms, R. E. Five-co-ordinate silicon. Kinetics of the acidcatalysed hydrolysis of nitrilotriphenoxysilanes. J. Chem. Soc. A 1971, 1969-1974.

(45) Srivastav, N.; Singh, R.; Kaur, V.; Wagler, J.; Kroke, E. A stannatrane-like $[4.4 .4 .01,6]$ heterotricyclic stannate anion possessing rhodanide antennae: A chromoreactand for $\mathrm{Fe}^{3+}, \mathrm{Cu}^{2+}$ and $\mathrm{Co}^{2+}$ ions. Inorg. Chim. Acta 2017, 463, 54-60.

(46) Whittaker, S. M.; Brun, M.-C.; Cervantes-Lee, F.; Pannell, K. H. Synthesis, structure, and reactivity of the permethylated decasilane $\left.\left(\mathrm{Me}_{3} \mathrm{Si}\right)_{3} \mathrm{SiSiMe}_{2} \mathrm{SiMe}_{2} \mathrm{SiMe}_{3}\right)_{3}$. J. Organomet. Chem. 1995, 499, 247252.

(47) Herman, A.; Dreczewski, B.; Wojnowski, W. Contributions to the chemistry of silicon-sulphur compounds: XLV. $\sigma$-Bond conjugation in silicon-sulphur catenates. J. Organomet. Chem. 1988, 339, 41-49.

(48) Pangborn, A. B.; Giardello, M. A.; Grubbs, R. H.; Rosen, R. K.; Timmers, F. J. Safe and Convenient Procedure for Solvent Purification. Organometallics 1996, 15, 1518-1520.

(49) Wallner, A.; Wagner, H.; Baumgartner, J.; Marschner, C.; Rohm, H. W.; Köckerling, M.; Krempner, C. Structure, Conformation, and UV Absorption Behavior of Partially Trimethylsilylated Oligosilane Chains. Organometallics 2008, 27, 5221-5229.

(50) Gilman, H.; Smith, C. L. Tetrakis(trimethylsilyl)silane. J. Organomet. Chem. 1967, 8, 245-253.

(51) (a) Marschner, C. A New and Easy Route to Polysilanylpotassium Compounds. Eur. J. Inorg. Chem. 1998, 221-226. (b) Jenkins, D. M.; Teng, W.; Englich, U.; Stone, D.; Ruhlandt-Senge, K. Heavy Alkali Metal Tris(trimethylsilyl)silanides: A Synthetic and Structural Study. Organometallics 2001, 20, 4600-4606.

(52) (a) Morris, G. A.; Freeman, R. Enhancement of nuclear magnetic resonance signals by polarization transfer. J. Am. Chem. Soc. 1979, 101, 760-762. (b) Helmer, B. J.; West, R. Enhancement of silicon-29 NMR signals by proton polarization transfer. Organometallics 1982, 1, 877879.

(53) SAINTPLUS: Software Reference Manual; Bruker-AXS: Madison, WI, 1997-2003.

(54) (a) Blessing, R. H. An empirical correction for absorption anisotropy. Acta Crystallogr., Sect. A: Found. Crystallogr. 1995, 51, 3338. (b) Sheldrick, G. M. SADABS, version 2.10; Bruker AXS Inc.: Madison, 2003.

(55) Sheldrick, G. M. A short history of SHELX. Acta Crystallogr., Sect. A: Found. Crystallogr. 2008, 64, 112-122.
(56) Farrugia, L. WinGX and ORTEP for Windows: an update. J. Appl. Crystallogr. 2012, 45, 849-854.

(57) POV-Ray, version 3.6; Persistence of Vision Pty. Ltd.: Williamstown, Victoria, Australia, 2004. Available online: http:// www.povray.org/download/ (accessed on Sept 07, 2008).

(58) Dovesi, R.; Orlando, R.; Civalleri, B.; Roetti, C.; Saunders, V. R.; Zicovich-Wilson, C. M. CRYSTAL: a computational tool for the $a b$ initio study of the electronic properties of crystals. Z. Kristallogr. Cryst. Mater. 2005, 220, 571-573.

(59) Nada, R.; Nicholas, J. B.; McCarthy, M. I.; Hess, A. C. Basis sets for ab initio periodic Hartree-Fock studies of zeolite/adsorbate interactions: $\mathrm{He}, \mathrm{Ne}$, and $\mathrm{Ar}$ in silica sodalite. Int. J. Quantum Chem. 1996, 60, 809-820.

(60) Grimme, S. Semiempirical GGA-type density functional constructed with a long-range dispersion correction. J. Comput. Chem. 2006, 27, 1787-1799.

(61) (a) Vener, M. V.; Manaev, A. V.; Egorova, A. N.; Tsirelson, V. G. QTAIM Study of Strong H-Bonds with the O-H...A Fragment $(\mathrm{A}=\mathrm{O}$, $\mathrm{N}$ ) in Three-Dimensional Periodical Crystals. J. Phys. Chem. A 2007, 111, 1155-1162. (b) Hathwar, V. R.; Thakur, T. S.; Dubey, R.; Pavan, M. S.; Guru Row, T. N.; Desiraju, G. R. Extending the Supramolecular Synthon Based Fragment Approach (SBFA) for Transferability of Multipole Charge Density Parameters to Monofluorobenzoic Acids and their Cocrystals with Isonicotinamide: Importance of $\mathrm{C}-\mathrm{H} \cdots \mathrm{O}$, $\mathrm{C}-\mathrm{H} \cdots \mathrm{F}$, and F $\cdots \mathrm{F}$ Intermolecular Regions. J. Phys. Chem. A 2011, 115, $12852-12863$.

(62) Tsirelson, V. G. Interpretation of Experimental Electron Densities by Combination of the QTAMC and DFT. In The Quantum Theory of Atoms in Molecules: from Solid State to DNA and Drug Design; Matta, C., Boyd, R., Eds.; Wiley-VCH, 2007; pp 257-283.

(63) Gatti, C. TOPOND98 User's Manual; CNR-CSRSRC: Milano, Italy, 1999.

(64) Vener, M. V.; Shishkina, A. V.; Rykounov, A. A.; Tsirelson, V. G. $\mathrm{Cl} \cdots \mathrm{Cl}$ Interactions in Molecular Crystals: Insights from the Theoretical Charge Density Analysis. J. Phys. Chem. A 2013, 117, 8459-8467. 